\title{
The Effect of High Pressure Techniques on the Stability of Anthocyanins in Fruit and Vegetables
}

\author{
Krystian Marszałek *, Łukasz Woźniak, Bartosz Kruszewski and Sylwia Skąpska \\ Department of Fruit and Vegetable Product Technology, Prof. Wacław Dabrowski Institute of Agricultural and \\ Food Biotechnology, 36 Rakowiecka Street, 02-532 Warsaw, Poland; lukasz.wozniak@ibprs.pl (Ł.W.); \\ bartosz.kruszewski@ibprs.pl (B.K.); sylwia.skapska@ibprs.pl (S.S.) \\ * Correspondence: krystian.marszalek@ibprs.pl; Tel.: +48-22-606-3603
}

Academic Editor: Nuno Mateus

Received: 19 December 2016; Accepted: 19 January 2017; Published: 27 January 2017

\begin{abstract}
Anthocyanins are a group of phenolic compounds responsible for red, blue and violet colouration of many fruits, vegetables and flowers. The high content of these pigments is important as it influences directly their health promoting properties as well as the sensory quality of the product; however they are prone to degradation by, inter alia, elevated temperature and tissue enzymes. The traditional thermal methods of food preservation cause significant losses of these pigments. Thus, novel non-thermal techniques such as high pressure processing, high pressure carbon dioxide and high pressure homogenization are under consideration. In this review, the authors attempted to summarize the current knowledge of the impact of high pressure techniques on the stability of anthocyanins during processing and storage of fruit and vegetable products. Furthermore, the effect of the activity of enzymes involved in the degradation of these compounds has been described. The conclusions including comparisons of pressure-based methods with high temperature preservation techniques were presented.
\end{abstract}

Keywords: anthocyanins; stability; degradation; high pressure processing; high pressure carbon dioxide; high pressure homogenization

\section{Introduction}

Consumption of fruit and vegetable products containing numerous bioactive compounds can significantly reduce the risk of various degenerative diseases. Much current research has been carried out on the content of different phytochemicals and their positive health effect. It has been demonstrated that a diet rich in fruit and vegetables is the source of polyphenols (phenolic acids, flavonols, catechin monomers, proanthocyanidins, flavones, flavanones and anthocyanins) [1]. From the consumer's point of view anthocyanins play the particularly important role because of their health promoting properties and impact on a key quality parameter, colour, influencing the sensory acceptance of the product.

Anthocyanins are the largest and the most diverse group of plant pigments responsible for the red, violet and blue colours of various fruit and vegetables [2-5]. These pigments are water-soluble phenolic compounds, located in vacuoles and part of a large group of flavonoids that have a common $\mathrm{C}_{6}-\mathrm{C}_{3}-\mathrm{C}_{6}$ structure consisting of two aromatic rings linked through an oxygenated heterocycle (Figure 1). The name of anthocyanins describes both aglycones (anthocyanidins) as well as their glycosides. While there are six common anthocyanidins found in plant tissues, more than 540 anthocyanin pigments have been identified in nature [6], with most of the structural variation coming from glycosidic substitution at the 3 and 5 positions and possible acylation of sugar residues with organic acids causing differences in their colour and stability [2,6]. Increased glycosidic substitution, and in particular, acylation of sugar residues, will increase pigment stability [6]. 


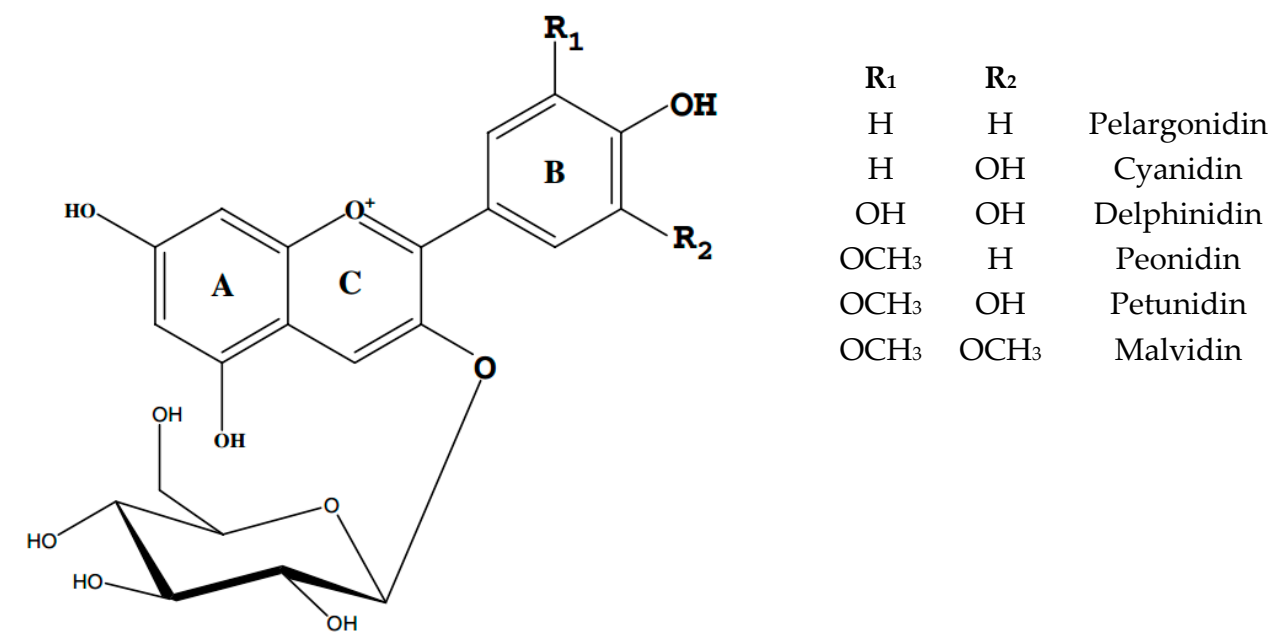

Figure 1. Structure of anthocyanins [5].

Polyphenols, especially anthocyanins, are effective antioxidants with a beneficial effect on human health and disease prevention. They can promote healthy vision, dermal health, have a positive effect on the cardiovascular system as well as exhibit neuroprotective, anticarcinogenic and antidiabetic properties [6-8]. Dietary consumption of anthocyanins, especially from red fruits, certain vegetables or red wines should be as high as $200 \mathrm{mg}$ per day. The "French Paradox" has been explained by the high consumption of resveratrol and other polyphenols, such as anthocyanins with red wine as a part of a diet rich in saturated fats.

Reduction of losses of anthocyanins is the target for food production. However, to achieve any biological effect in the human body, anthocyanins must be bioavailable, i.e., effectively absorbed from the gastrointestinal tract into the circulation and delivered to the appropriate location within the body. Studies of the oral intake of anthocyanins-rich fruits have confirmed increased antioxidant status of the serum $[9,10]$, despite very low bioavailability of these compounds $(1 \%-4 \%$ of dose uptake) $[5,11,12]$.

Many foods that contain anthocyanins are thermally processed prior to consumption and this process can significantly influence the degradation of anthocyanins and vitamin $\mathrm{C}$ content in the final product. The degradation level of anthocyanins may be as high as $50 \%$, depending on the temperature and the heating time $[4,13]$. Thermal processing implies heating up to $50-150{ }^{\circ} \mathrm{C}$, depending on the $\mathrm{pH}$ of the product and the desired shelf life. Consumer demand for nutritious foods, which are minimally processed, without using artificial preservative substances, has led to an interest in non-thermal technologies, such as high pressure processing, high pressure carbon dioxide or high pressure homogenization [14]. These techniques, based on elevated pressure, are employed at ambient or mild temperatures, thereby avoiding negative thermal effects on food nutritional and sensorial quality parameters [15].

The present review will summarize and critically evaluate recent studies on the effect of high pressure techniques on the anthocyanin content in fruit and vegetable products. Particular focus will be given to the degradation of anthocyanins subjected to these techniques with the special consideration for the kinetics and mechanisms of these reactions, including enzymatic decomposition.

\section{The Principles and Food Applications of High Pressure Techniques}

\subsection{High Pressure Processing (HPP)}

High hydrostatic pressure processing (HHP), high pressure processing (HPP) or ultra-high pressure (UHP) is a non-thermal technique used in food preservation, starch gelatinization, enzyme inactivation, osmotic drying enhancement, pressure-shift freezing and thawing enhancement $[3,4,16-18]$. HPP is derived from material science in which samples are treated with 
pressures above $100 \mathrm{MPa}$ [3] and is an interesting alternative to traditional food preservation [19]. High pressure affects noncovalent bonds (such as hydrogen, ionic, and hydrophobic bonds) substantially as such bonds are usually very sensitive to pressure. The low molecular weight food components (those responsible for nutritional and sensory characteristic) are not affected by pressure whereas high molecular weight components (whose tertiary structure is important for functionality determination i.e., proteins) are pressure sensitive $[8,16]$.

The application of high pressures to food preservation started around 1900 when the Hite group investigated its effect on milk, meat, fruits and vegetables at pressures up to $650 \mathrm{MPa}$ and noted significant reduction of microbes [18]. The first commercial products processed by hydrostatic pressure were launched in Japan in 1990. Since then, researchers and industrial companies have explored this technique, especially in Japan, Europe and US.

There are two major limitations to the further development of HPP. First, the database of pressure processing kinetics parameters of microbial and enzyme inactivation, such as $D$-value and $z$-value, is not comprehensive enough to ensure the reliability of HPP as an alternative to thermal processing. Secondly, developing a continuous pressure food processor remains an engineering challenge [18]. The highest advantages of HPP techniques are the fresh taste and natural colour of preserved products.

\subsection{High Pressure Carbon Dioxide (HPCD)}

HPCD is a method of cold pasteurization that inactivates food microorganisms and tissue enzymes through the combined effect of high pressure, mild heat and the ability of carbon dioxide to penetrate food samples. This technology is already over 50 years old, however so far it has not been implemented in large-scale food industry processes. Similarly to HHP, this technique is described by several names, including Dense Phase Carbon Dioxide (DPCD) and, when used under specific pressure and temperature conditions, Supercritical Carbon Dioxide (SCCD).

The microbial inactivation during the HPCD processing is usually connected with lowering $\mathrm{pH}$ inside the cell, physical disruption of microbiota, modification of cell membranes and extraction of intracellular compounds. The rewarding decontamination effect is possible to achieve with minimum tenfold lower pressure compared to pressure used in HPP. The most important advantages of this technique is the possibility of microbial and tissue enzymes inactivation under much lower pressures compared to HPP technique. Still, the exact mechanism of enzyme inactivation still remains unclear; one of the main hypotheses describes the conformational changes of the enzymes.

Several HPCD treatment systems have been developed. In batch systems samples are placed inside a thermostated pressure chamber, $\mathrm{CO}_{2}$ is pumped in and left for some period of time to ensure penetration. The continuous systems include membrane contractors, micropore filters or a continuous flow of the sample and carbon dioxide. HPCD is usually tested for use in liquid foods, such as fruit juices, beer and milk. Treatment of whole fruits was unsuccessful due to severe tissue damage [20].

\subsection{High Pressure Homogenization (HPH)}

HPH is a new technology developed as a result of food producers' need to obtain new quality products with increased or well preserved pro-healthy compounds, such as vitamins and polyphenols [21-26]. It is based on the same principle as traditional homogenization but employs $10-15$ times higher pressures within a range from 100 up to $400 \mathrm{MPa}$. The process carried out at upper pressure range $\geq 200 \mathrm{MPa}$ is called an ultra-high pressure homogenization (UHPH) [25-27].

The principle of HPH is forcing the pressurized liquid through a gap of a few micrometers in width (disruption valve), where it is submitted to rapid acceleration. The resulting pressure drop simultaneously generates intense fluid-mechanical stresses such as local cavitation, shear stress, collision, and turbulence which lead to particle comminution [21,28,29]. For this reason, HPH is a suitable and effective technology for the continuous dynamic production of fluid like and pumpable foods. The main industrial application of HPH is the production of stable vegetable and livestock milk emulsions and their by-products [26,29-32]. This non-thermal technology is also investigated 
for the production of high quality fruit and vegetable juices and beverages $[23,25,33-36]$. The biggest advantages of HPH in cloudy juices are simultaneous microbial preservation and the stabilization effect. Other industries with high applicability potential are cosmetology and pharmaceutics $[37,38]$.

Reducing the particles and emulsion droplets to finer dimensions modifies the physical characteristics of liquid or semi-liquid mixtures, such as the viscosity and mean particle size of the suspended solids, which affect texture and promote freshness attributes [21,33]. High pressure present during homogenization, especially above $200 \mathrm{MPa}(\mathrm{UHPH})$ has been shown to have great results in the reduction of pathogenic and spoilage microorganisms by microbial cell disruption without decreasing the nutritional value of processed food products $[29,33,36,39-41]$. Studies have shown that the level of inactivation of the microbial load depended on the applied pressure, number of HPH passes, inlet and valve temperatures, matrix type and the nature of microflora [31,33,36,42-44]. The most sensitive to HPH are yeast and moulds, more robust are gram negative bacteria, while gram positive bacteria are the most resistant $[31,32,45,46]$.

In general, raising the homogenization pressure and inlet/valve temperatures significantly increased the reduction of microorganisms. However, with increasing pressure the temperature in the valve also increases (adiabatic heating about $0.15-0.20^{\circ} \mathrm{C} / \mathrm{MPa}$ ), so it is important to monitor and adjust both parameters not to generate excessive heating with a negative impact on nutritional value and the loss of biomolecule functionality of processed foods $[22,25,28,33]$. In most cases, efficient, rapid cooling systems were installed after the homogenizer valve $[26,34,35,47]$. The effectiveness of $\mathrm{HPH}$ treatment for given pressure can be improved by performing multiple passes $[36,43,45,46]$. Some authors have found a first order inactivation kinetics as a function of the number of passes $[45,46]$.

\section{Anthocyanins Stability Factors}

\subsection{Role of Enzymes in Anthocyanins Degradation}

Enzymes, such as $\beta$-glucosidase ( $\beta$-GLC), polyphenoloxidase (PPO) and peroxidase (POD), are mainly responsible for the degradation of anthocyanins. The anthocyanin-degrading enzymes may be native, present in the plant tissue, or they may result as a product of microbial contamination [6]. Another possible source is the side activity of commercial enzyme preparations used for technological reasons during industrial juice extraction.

The search of anthocyanins-degrading enzymes is performed on postharvest fruit and vegetables, during processing and storage. Intercellular decompartmentation and cell layer reparation begins during storage, and the pigments may be exposed to microenvironmental conditions that differ from those in growing plants, including enzymes that are not located in the vacuoles when the plant cells are intact [2].

$\beta$-GLC (EC 3.2.1.21) influences directly the anthocyanins, but the action of PPO (EC 1.14.18.1) and POD (EC 1.11.1.7) is indirect [6]. $\beta$-GLC catalyzes the hydrolysis of aryl or alkyl $\beta$-D-glucosides and is involved in the liberation of aglycones from non-volatile glucosides [48]. These enzymes catalyze the loss of glycosidic moiety leading to the formation of anthocyanidin consequently affecting product colour. Specificity of $\beta$-glucosidase leads to a reduction of anthocyanins containing glucose in their structure because of the greater affinity towards glucose compared to other sugars [3]. PPO and POD are the principal enzymes involved in the enzymatic browning of plant tissues. PPOs are copper-containing isoenzymes responsible for the hydroxylation of monophenols to $o$-diphenols (by monophenol oxidase) and the oxidation of diphenols to quinones (by diphenol oxidase) which in the presence of proteins form complex brown pigments [49,50]. POD carries a " $b$ "-type heme as a prosthetic group and, as another redox enzyme, participates in several plant metabolic processes such as the catabolism of auxins, lignification of the cell wall, as well as browning reactions, resulting in products which participate in the oxidation of various electron donors with $\mathrm{H}_{2} \mathrm{O}_{2}$ [51].

It was proposed that anthocyanins are firstly hydrolyzed by the $\beta$-glucosidase, forming anthocyanidins which can be oxidized by polyphenol oxidase and/or peroxidase (Figure 2). PPO at 
the presence of oxygen can accelerate the enzyme degradation of anthocyanins. Oxidation of simply phenols, resulting from PPO activity, leads to the formation of the corresponding o-quinones, which may then accelerate anthocyanins degradation in the oxidative reaction. These quinones react with anthocyanins to form brown condensation products [4]. This observation confirms that PPO plays a vital role in anthocyanins degradation. Peroxidases also degrade anthocyanins in fruit and vegetable products provoked by the $\mathrm{H}_{2} \mathrm{O}_{2}$ present in plant cells [2,4]. The other pathway of anthocyanin changes in fruit and vegetable products are non-enzymatic chain reactions due to hydrolysis of glucosidic linkage to form aglycone or hydrolytic cleavage of pyrilium ring to form substituted chalcones. Thermal degradation is assumed to be a hydrolytic reaction and availability of water is essential for anthocyanins degradation [52].

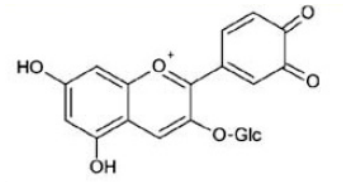

Anthocyanin o-quinone

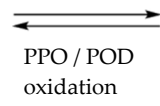

oxidation

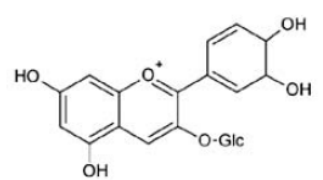

Anthocyanin (i.e. Cyanidin-3-glucoside)

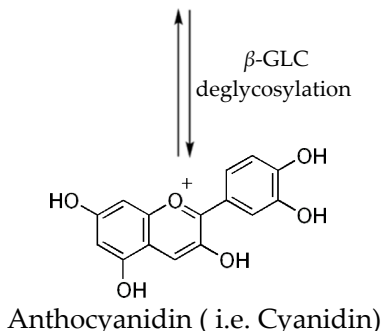

Monophenol

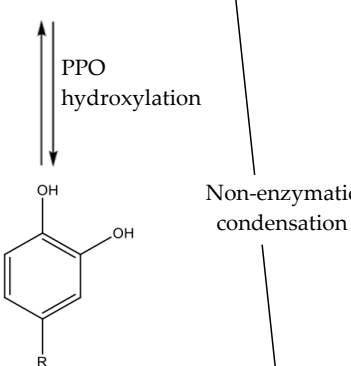

Diphenol

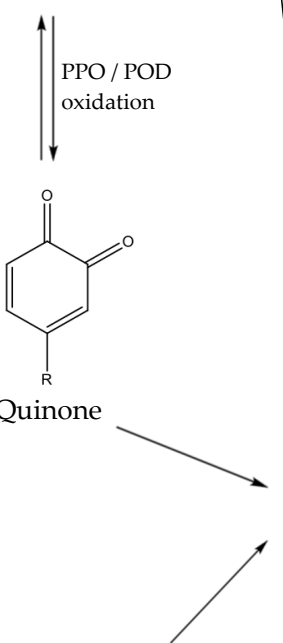

Amino acids
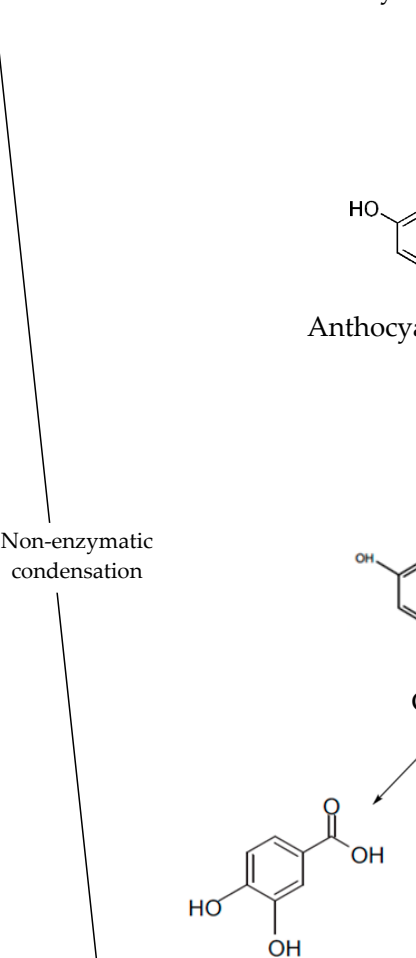

Benzoic acid derivatives (i.e. Protocatechuic acid)
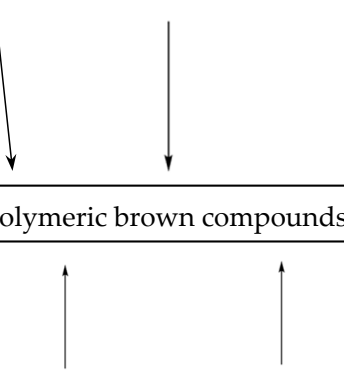

Proteins

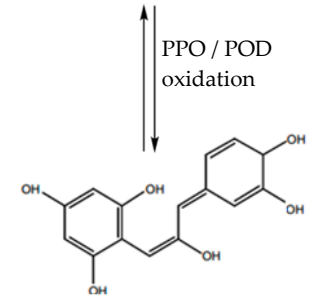

Chalcone

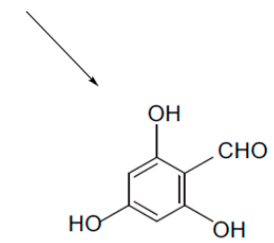

Trihydroxybenzaldehyde (Phloroglucinaldehyde)

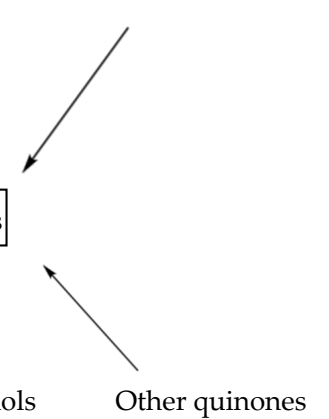

Figure 2. Scheme describing anthocyanins degradation. PPO: polyphenol oxidase, POD: peroxidase, $\beta$-GLC: beta glycosidase. 
Pressure techniques can influence the enzyme activity responsible for anthocyanins stability. The inactivation effect depends on many factors, such as pressure, temperature and processing time as well as the physicochemical properties of raw materials such as total soluble solids and $\mathrm{pH}[3,48]$. From the industrial point of view it is important to care about reduction as many factors accelerating enzymatic reaction as possible, i.e., oxygen or temperature.

\subsection{Other Factors Affecting Anthocyanin Stability}

Anthocyanins are very susceptible to degradation not only through the activity of tissue enzymes but through other factors such as temperature, light, $\mathrm{pH}$, sugars, presence of oxygen, sulphites, ascorbic acid, metal ions and co-pigments [18,52-54]. The stabilization of anthocyanins in different mixed products can be achieved by the increasing of acidity for example by carefully composing recipes or addition of organic acids. The colour and stability of anthocyanin solutions are dependent on equilibrium of 4 species due to changes in $\mathrm{pH}$, protonation or hydratation reactions. Anthocyanins exist primarily in the form of red flavylium cations at $\mathrm{pH}<3$. As the $\mathrm{pH}$ is raised, kinetics and thermodynamic competition occurs between the hydration reaction on position 2 of the flavyium cation and the proton transfer reaction related to its acidic hydroxyl groups. This flavylium cation converts into purple-violet quinonoidal bases as $\mathrm{pH}$ increases to 4 . At $\mathrm{pH} 4-6$, nucleophilic attack by water at C-2 yields colorless hemiketal forms, which can undergo ring opening to yield yellow retro-chalcones [52,55]. The degradation of anthocyanins is also affected by solution composition and environmental conditions such as oxygen concentration [56]. The oxygen is an important factor in enzymatic reactions described earlier.

On the other hand, the stability of anthocyanins is increased by copigmentation that occurs in the presence of certain compounds such as other phenolics and metal ions such as magnesium, copper and aluminium [53]. Anthocyanins under different processing and storage conditions readily convert into insoluble polymeric brown pigments. This pigments also rapidly degrade at elevated temperature due to their high reactivity causing monomeric anthocyanins to polymerize forming brown compounds [52].

The structure of anthocyanins plays a crucial role in their stability. In general, the presence of hydroxyl groups $(-\mathrm{OH})$ decreases stability of the molecule, while the occurrence of methoxy groups $(-\mathrm{OCH} 3)$ increases it [57]. The stability of anthocyanins is also increased by the bigger number of sugar moieties and their acylation by aliphatic and cinnamic acids $[7,52,58]$. In nature, the hydroxyl groups of the substituted glycosyls of anthocyanins are typically acylated by organic acids via ester bonds, which is referred to as anthocyanins glycosyl acylation, to yield acylated anthocyanins. Anthocyanin glycosyl acylation affects their chemical stability anthocyanins. Glycosyl acylation is one of the key factors for creating diversity within anthocyanins molecules and the types, numbers and linkage position of the acyl groups substantially increase the types of anthocyanins and their stability [59].

The stability can be also increased by the formation of addicts made of two molecules of anthocyanins (self-association) or anthocyanin and other compounds (co-pigmentation). The copigmentation occurs most often between anthocyanin and other phenolics like hydroxycinnamic acids [53].

\section{Inactivation of Enzymes Responsible for Degradation of Anthocyanins during Pressure Processes}

\subsection{High Pressure Processing (HPP)}

High pressure can have an influence on the biochemical reactions, since it is able to change the quaternary structure of proteins. The effect of HPP on the proteins/enzymes is reversible up to $400 \mathrm{MPa}$ and is linked with the conformational changes, subunit dissociation and association process [60]. High pressure treatment generally leads to a reduction of the fruit and vegetable tissue enzymes activity [61-67], but there are also some results proving that pressure can increase the activity 
of enzymes [68-70]. A significant decrease of selected enzymes activity were noted in fruits such as: apples, avocado, grapes, pineapple, strawberry, raspberry and feijoa under a pressure range from 400 to $900 \mathrm{MPa}$, depending on food composition and $\mathrm{pH}$. At a lower pressure range from 50 to $400 \mathrm{MPa}$ some authors observed even enhanced enzyme activity [66,67]. Moreover, higher pressure induced inactivation of tissue enzymes was found at a lower $\mathrm{pH}$ [71]. Apart from the $\mathrm{pH}$, pressure inactivation was also influenced by the addition of salts, sugars and other compounds such as benzoic acid, glutathione or calcium chloride [72]. The application of pressure under commercial units allowed to complete the inactivation of enzymes only in a combination with mild temperature $\left(\sim 50^{\circ} \mathrm{C}\right)$. The influence of HPP on three of the most important enzymes responsible for anthocyanins degradation found in fruit and vegetables, polyphenol oxidase (PPO), peroxidase (POD) and $\beta$-glucosidase ( $\beta$-GLC), was presented in Table 1. Generally speaking the application of HPP allows only to decrease the activity of selected tissue enzymes. Complete inactivation is possible but with pressure over the pressures achievable in industrial applications. The use of lower pressure can be compensated by longer time of the process, which however may significantly decrease the efficiency of production.

Table 1. Effect of HPP on the stability of selected fruit and vegetable enzymes.

\begin{tabular}{|c|c|c|c|c|}
\hline Enzyme & Source & Processing Conditions & Effect & Reference \\
\hline & Apples & $300-700 \mathrm{MPa}, 25^{\circ} \mathrm{C}, 1 \mathrm{~min}$ & Activation at $300 \mathrm{MPa}$ and inactivation at $700 \mathrm{MPa}$ & [68] \\
\hline & Avocados & Up to $900 \mathrm{MPa}, 25-77^{\circ} \mathrm{C}$ & Pressure increase caused a decrease in inactivation rate & [72] \\
\hline & Onions & $>700 \mathrm{MPa}, 25^{\circ} \mathrm{C}, 10 \mathrm{~min}$ & Activation, maximal at $500 \mathrm{MPa}$ & [70] \\
\hline & Pears & $400,25^{\circ} \mathrm{C}, 10 \mathrm{~min}$ & Activation & [69] \\
\hline & Pears & $900 \mathrm{MPa}, 25^{\circ} \mathrm{C}$ & slight inactivation & [72] \\
\hline & White grapes & $700 \mathrm{MPa}, 25^{\circ} \mathrm{C}$ & inactivation & [72] \\
\hline & Pineapples & $\begin{array}{l}\text { 200-600 MPa, } 30-70{ }^{\circ} \mathrm{C}, \\
5-20 \mathrm{~min}\end{array}$ & $\begin{array}{l}25 \% \text { and } 70 \% \text { maximum inactivation at } 600 \mathrm{MPa} \text { for } \\
20 \mathrm{~min} \text { and } 30 \text { and } 70{ }^{\circ} \mathrm{C} \text {, respectively }\end{array}$ & [67] \\
\hline & Feijoas & $\begin{array}{l}200-600 \mathrm{MPa}, 1-13 \mathrm{~min}, \\
\text { room temperature }\end{array}$ & Maximum $30 \%$ inactivation at 600 for $7 \mathrm{~min}$ & [66] \\
\hline & Strawberries & $\begin{array}{l}200-600 \mathrm{MPa}, 5-15 \mathrm{~min}, \\
\text { room temperature }\end{array}$ & $\begin{array}{l}\text { Slight activation at } 200 \mathrm{MPa} \text {, and up to } 80 \% \text { inactivation } \\
\text { at } 600 \mathrm{MPa} \text { for } 15 \mathrm{~min}\end{array}$ & [73] \\
\hline & $\begin{array}{l}\text { Red raspberries, } \\
\text { strawberries }\end{array}$ & $400-800 \mathrm{MPa}, 18$ and $22{ }^{\circ} \mathrm{C}$ & $\begin{array}{l}30 \% \text { inactivation at } 800 \mathrm{MPa} \text { after } 15 \mathrm{~min} \text { treatment in } \\
\text { raspberries, total inactivation after } 15 \mathrm{~min} \text { at } 600 \text { and } \\
800 \mathrm{MPa} \text { and after } 10 \mathrm{~min} \text { at } 800 \mathrm{MPa} \text { in strawberries }\end{array}$ & [74] \\
\hline & Strawberry puree & $\begin{array}{l}100-690 \mathrm{MPa}, 24-90^{\circ} \mathrm{C}, \\
5-15 \mathrm{~min}\end{array}$ & $24 \%$ inactivation at $690 \mathrm{MPa}$ and $90^{\circ} \mathrm{C}$ for 5 and $15 \mathrm{~min}$ & [63] \\
\hline & Strawberries & $\begin{array}{l}300-600 \mathrm{MPa}, 20-60^{\circ} \mathrm{C}, \\
2-10 \mathrm{~min}\end{array}$ & $\begin{array}{l}\text { Maximum } 29 \% \text { inactivation at } 600 \mathrm{MPa} \text { for } 10 \mathrm{~min} \text { and } \\
60^{\circ} \mathrm{C}\end{array}$ & [62] \\
\hline & $\begin{array}{l}\text { Strawberries } 3 \\
\text { cultivars }\end{array}$ & $600 \mathrm{MPa}, 20^{\circ} \mathrm{C}, 5 \mathrm{~min}$ & $20 \%-40 \%$ of inactivation depending on cultivar & [64] \\
\hline \multirow[t]{13}{*}{ PPO } & $\begin{array}{l}\text { Strawberry puree } \\
\text { with } 10 \% \text { of sugar }\end{array}$ & $\begin{array}{l}200-600 \mathrm{MPa}, 40-80^{\circ} \mathrm{C}, \\
2.5-10 \mathrm{~min}\end{array}$ & Maximum $50 \%$ inactivation & [75] \\
\hline & Strawberry pulp & $\begin{array}{l}400-600 \mathrm{MPa}, 5-25 \mathrm{~min}, \\
\text { room temperature }\end{array}$ & $51 \%$ inactivation at $600 \mathrm{MPa}$ for $25 \mathrm{~min}$ & [65] \\
\hline & Strawberry puree & $50-400 \mathrm{MPa}, 20-60^{\circ} \mathrm{C}$ & $60 \%$ inactivation under $250 \mathrm{MPa}$ and $20^{\circ} \mathrm{C}$, & [61] \\
\hline & Strawberry puree & $\begin{array}{l}300-500 \mathrm{MPa}, 0-50{ }^{\circ} \mathrm{C}, \\
5-15 \mathrm{~min}\end{array}$ & $72 \%$ inactivation at $500 \mathrm{MPa}, 15 \mathrm{~min}, 50^{\circ} \mathrm{C}$ & [13] \\
\hline & Strawberry puree & $\begin{array}{l}300-600 \mathrm{MPa}, 50^{\circ} \mathrm{C}, \\
15 \mathrm{~min}\end{array}$ & $\begin{array}{l}58 \% \text { and } 41 \% \text { of inactivation at } 300 \text { and } 600 \mathrm{MPa}, 15 \mathrm{~min} \text {, } \\
50{ }^{\circ} \mathrm{C} \text {, respectively }\end{array}$ & [76] \\
\hline & Spinach & $700 \mathrm{MPa}, 20^{\circ} \mathrm{C}, 15 \mathrm{~min}$ & $86 \%$ inactivation & [77] \\
\hline & Mango pulp & $\begin{array}{l}400-600 \mathrm{MPa}, 40-60^{\circ} \mathrm{C}, \\
5-15 \mathrm{~min}\end{array}$ & Up to $63 \%$ inactivation at the harshest conditions & [78] \\
\hline & Blueberry & $0.1-700 \mathrm{MPa}, 30-80{ }^{\circ} \mathrm{C}$ & $\begin{array}{l}\text { Up to } 6 \text { fold increase activity at } 500 \mathrm{MPa} \text { and } 30^{\circ} \mathrm{C} \text {, } \\
\text { significant decrease at minimum } 500 \mathrm{MPa} \text { and } \\
\text { temperature over } 76^{\circ} \mathrm{C}\end{array}$ & [79] \\
\hline & Pumpkin puree & $\begin{array}{l}300-900 \mathrm{MPa}, 60-80{ }^{\circ} \mathrm{C}, \\
1 \mathrm{~min}\end{array}$ & Up to $60 \%$ inactivation at $900 \mathrm{MPa}$ and $70{ }^{\circ} \mathrm{C}$ & [80] \\
\hline & Cloudy apple juice & $600 \mathrm{MPa}, 3 \mathrm{~min}$ & Up to $50 \%$ inactivation & [81] \\
\hline & Wild berries & $\begin{array}{l}\text { 200-600 } \mathrm{MPa} \text {, room } \\
\text { temperature, 5-30 min }\end{array}$ & $\begin{array}{l}\text { Up to } 3 \text { fold increase activity at } 200 \mathrm{MPa}, 5 \mathrm{~min} \text { and } \\
\text { insignificant inactivation at harshest conditions }\end{array}$ & [82] \\
\hline & Beet root & $650 \mathrm{MPa}, 3-30 \mathrm{~min}$ & $10 \%-25 \%$ inactivation depending on time & [83] \\
\hline & Peach & $\begin{array}{l}600 \mathrm{MPa}, 20-100{ }^{\circ} \mathrm{C}, \\
3-5 \mathrm{~min}\end{array}$ & $\begin{array}{l}68 \% \text { inactivation at } 20^{\circ} \mathrm{C} \text { for } 5 \mathrm{~min} \text { and } 90 \% \text { inactivation } \\
\text { at } 80-100{ }^{\circ} \mathrm{C} \text { after } 3 \mathrm{~min}\end{array}$ & [84] \\
\hline
\end{tabular}


Table 1. Cont.

\begin{tabular}{|c|c|c|c|c|}
\hline Enzyme & Source & Processing Conditions & Effect & Reference \\
\hline \multirow{16}{*}{ POD } & Strawberries & $400-800 \mathrm{MPa}, 18$ and $22{ }^{\circ} \mathrm{C}$ & $\begin{array}{l}11 \%-35 \% \text { inactivation at } 600 \mathrm{MPa} \text { for } 15 \mathrm{~min} \\
\text { in strawberries }\end{array}$ & [74] \\
\hline & Strawberry puree & $\begin{array}{l}100-690 \mathrm{MPa}, 24-90^{\circ} \mathrm{C}, \\
5-15 \mathrm{~min}\end{array}$ & $\begin{array}{l}97 \% \text { inactivation at } 100 \mathrm{MPa} \text { and } 90^{\circ} \mathrm{C} \text { for } 15 \mathrm{~min} \text {, } \\
35 \% \text { inactivation at the same pressure and the } \\
\text { lowest temperature }\end{array}$ & [63] \\
\hline & Strawberries & $\begin{array}{l}300-600 \mathrm{MPa}, 20-60^{\circ} \mathrm{C} \\
2-10 \mathrm{~min}\end{array}$ & $\begin{array}{l}\text { Maximum 59\% inactivation at } 600 \mathrm{MPa} \text { for } 2 \mathrm{~min} \text { and } \\
60^{\circ} \mathrm{C}\end{array}$ & [62] \\
\hline & $\begin{array}{l}\text { Strawberries of } \\
\text { three cultivars }\end{array}$ & $600 \mathrm{MPa}, 20^{\circ} \mathrm{C}, 5 \mathrm{~min}$ & $40 \%$ inactivation & [64] \\
\hline & Strawberry puree & $50-400 \mathrm{MPa}, 20-60^{\circ} \mathrm{C}$ & $50 \%$ inactivation under $230 \mathrm{MPa}$ and $43^{\circ} \mathrm{C}$ & [61] \\
\hline & Strawberry pulp & $\begin{array}{l}400-600 \mathrm{MPa}, 5-25 \mathrm{~min}, \\
\text { room temperature }\end{array}$ & $74 \%$ inactivation at $600 \mathrm{MPa}$ for $25 \mathrm{~min}$ & [65] \\
\hline & Pineapples & $\begin{array}{l}200-600 \mathrm{MPa}, 30-70{ }^{\circ} \mathrm{C}, \\
5-20 \mathrm{~min}\end{array}$ & $\begin{array}{l}25 \% \text { and } 80 \% \text { maximum inactivation at } 600 \mathrm{MPa} \text { for } \\
20 \mathrm{~min} \text { and } 30 \text { and } 70{ }^{\circ} \mathrm{C} \text {, respectively }\end{array}$ & [67] \\
\hline & Feijoas & $\begin{array}{l}200-600 \mathrm{MPa}, 1-13 \mathrm{~min}, \\
\text { room temperature }\end{array}$ & $\begin{array}{l}\text { Maximum } 24 \% \text { inactivation at } 400 \text { for } 13 \mathrm{~min} \text { and } \\
600 \mathrm{MPa} \text { for } 7 \mathrm{~min}\end{array}$ & [66] \\
\hline & Strawberry puree & $\begin{array}{l}300-500 \mathrm{MPa}, 0-50{ }^{\circ} \mathrm{C}, \\
5-15 \mathrm{~min}\end{array}$ & $50 \%$ inactivation at $500 \mathrm{MPa}, 15 \mathrm{~min}, 50^{\circ} \mathrm{C}$ & [13] \\
\hline & Strawberry puree & $\begin{array}{l}300-600 \mathrm{MPa}, 50^{\circ} \mathrm{C}, \\
15 \mathrm{~min}\end{array}$ & $\begin{array}{l}31 \% \text { and } 83 \% \text { inactivation at } 300 \text { and } 600 \mathrm{MPa}, 15 \mathrm{~min} \text {, } \\
50{ }^{\circ} \mathrm{C} \text {, respectively }\end{array}$ & [76] \\
\hline & Spinach & $700 \mathrm{MPa}, 20^{\circ} \mathrm{C}, 15 \mathrm{~min}$ & $77 \%$ inactivation & [77] \\
\hline & Mango pulp & $\begin{array}{l}400-600 \mathrm{MPa}, 40-60^{\circ} \mathrm{C}, \\
5-15 \mathrm{~min}\end{array}$ & Up to $67 \%$ inactivation at the harshest conditions & [78] \\
\hline & Cloudy apple juice & $600 \mathrm{MPa}, 3 \mathrm{~min}$ & Up to $50 \%$ inactivation & [81] \\
\hline & Wild berries & $\begin{array}{l}\text { 200-600 MPa, room } \\
\text { temperature, 5-30 min }\end{array}$ & $\begin{array}{l}\text { Up to } 3 \text { fold increase activity at } 200 \mathrm{MPa}, 5 \mathrm{~min} \text { and } \\
\text { insignificant inactivation at harshest conditions }\end{array}$ & [82] \\
\hline & Beet root & $650 \mathrm{MPa}, 3-30 \mathrm{~min}$ & Up to $25 \%$ inactivation & [83] \\
\hline & Peach & $\begin{array}{l}600 \mathrm{MPa}, 20-100^{\circ} \mathrm{C}, \\
3-5 \mathrm{~min}\end{array}$ & $\begin{array}{l}26 \% \text { inactivation at } 20^{\circ} \mathrm{C} \text { for } 5 \mathrm{~min} \text { and } 92 \% \text { inactivation } \\
\text { at } 80-100{ }^{\circ} \mathrm{C} \text { after } 3 \mathrm{~min}\end{array}$ & [84] \\
\hline \multirow{3}{*}{$\beta$-GLC } & $\begin{array}{l}\text { Red raspberries, } \\
\text { strawberries }\end{array}$ & $400-800 \mathrm{MPa}, 18$ and $22{ }^{\circ} \mathrm{C}$ & $\begin{array}{l}10 \% \text { inactivation at } 600 \text { and } 800 \mathrm{MPa} \text { for } 15 \mathrm{~min} \text { in } \\
\text { raspberries, } 50 \% \text { and } 60 \% \text { reduction at } 600 \text { and } 800 \mathrm{MPa} \\
\text { for } 15 \mathrm{~min} \text { in strawberries }\end{array}$ & [74] \\
\hline & Strawberry pulp & $\begin{array}{l}400-600 \mathrm{MPa}, 5-25 \mathrm{~min}, \\
\text { room temperature }\end{array}$ & $41 \%$ inactivation at $600 \mathrm{MPa}$ for $25 \mathrm{~min}$ & [65] \\
\hline & Strawberries & $\begin{array}{l}200-800 \mathrm{MPa} \text {, room } \\
\text { temperature, } 15 \mathrm{~min}\end{array}$ & $\begin{array}{l}\text { Increase of about } 50 \% \text { and } 70 \% \text { at } 200 \text { and } 400 \mathrm{MPa} \text {, } \\
\text { decrease of about } 50 \% \text { and } 65 \% \text { at } 600 \text { and } 800 \mathrm{MPa} \text {. }\end{array}$ & [85] \\
\hline
\end{tabular}

\subsection{High Pressure Carbon Dioxide (HPCD)}

The impact of dense phase carbon dioxide on the activity of tissue enzymes in strawberry juice has been reported in two works of Marszałek et al. [85,86]. Authors tested influence of HPCD at pressure up to $60 \mathrm{MPa}$, time up to $30 \mathrm{~min}$ and temperature up to $65^{\circ} \mathrm{C}$. It was shown that activity of polyphenol oxidase was fully inhibited after treatment at the temperatures of 45 and $65^{\circ} \mathrm{C}$ with the use of pressures of 10-60 MPa and treatment times of 10-30 min. On the other hand, no full inactivation of peroxidases has been achieved at these conditions; the best results (reduction to $<10 \%$ of initial activity) were observed for samples processed at $65^{\circ} \mathrm{C}$, regardless of pressure and time. The activity of enzymes has not changed significantly during the 12 weeks of storage of the processed juice. The team led by Gui [87] has been focusing on the impact of supercritical carbon dioxide on native polyphenol oxidase in cloudy apple juice. The maximum reduction of activity was more than $60 \%$ after processing at $55{ }^{\circ} \mathrm{C}$ and $30 \mathrm{MPa}$ for $60 \mathrm{~min}$, whereas Del Pozo-Insfran et al. [88] noted ca. 40\% inactivation of the same enzyme in muscadine grape juice treated by dense phase carbon dioxide at pressure up to $48 \mathrm{MPa}$. The impact of HPCD on the quality of carrot juice was investigated by Zhou et al. [89]. The researchers used a batch system to treat juice at a temperature of $25^{\circ} \mathrm{C}$, pressure of $10-30 \mathrm{MPa}$ and treatment times of $15-60 \mathrm{~min}$ and found out that residual activity of polyphenol oxidase was about $2 \%-4 \%$ of the initial one. Spilimbergo with co-workers dealt with HPCD preservation of fresh-cut carrot slices [90]. They used pressure of 8 and $12 \mathrm{MPa}$, temperature from 22 to $45^{\circ} \mathrm{C}$ and processing time $5-45 \mathrm{~min}$. The full inactivation of tissue enzymes has not been achieved, however a $70 \%$ reduction of activity after the treatment was observed. Another report by Niu et al. [91] was focused on apple slices. The scope of 
work included experiments at a pressure of $20 \mathrm{MPa}$, temperature range $25-65^{\circ} \mathrm{C}$; each of the processes was $20 \mathrm{~min}$ long. The experiments showed that in all tested parameters carbon dioxide treatment was able to fully suppress the activity of PPO in apples. The possibility of inactivation of tissue enzymes by HPCD is significantly higher compared to traditional HPP technique probably due to decreasing of $\mathrm{pH}$ of treated sample. In many cases, the total inactivation of selected enzymes in acidic products was achieved at minimum tenfold lower pressures compared to HPP. Pressurization with carbon dioxide causes significant changes of $\mathrm{pH}$ due to formation of carbonic acid, influencing on the enzyme activity. Changes in enzyme activity under HPCD may be also attributed to changes in protein structure, enzyme stability and/or disruption of enzyme-substrate interactions under the conditions of processing [88]. Some authors connected lowering of enzyme activity with changes in secondary structure (enzyme conformation) that was dependent on the kind of source $[87,88]$. Alternatively, the $\mathrm{pH}$ alternation by carbon dioxide might be associated with enzyme-bound arginine reactions to form a bicarbonate-protein complex that was potentially responsible for the decreasing of enzyme activity [88]. Further research is desirable in this field as well as the elaboration of relative industrial appliances for preservation of food products using HPCD.

\subsection{High Pressure Homogenization (HPH)}

Residual endogenous enzymes activity like PPO or POD in particular fruit or vegetable products treated with $\mathrm{HPH}$ can vary, and depend on the device type, processing method, especially the number of steps, their duration, and heating temperature [33]. In addition, pretreatment operations like thawing and blanching can markedly affect the enzymes activity, as well as anthocyanins content $[92,93]$.

Within the context of bioactive compounds retention, native enzymes inactivation is carefully studied in terms of application of HPH in food processing. So far, reports on HPH inactivation of enzymes which are related to food quality concerned: pectin methylesterase (PME), polygalacturonase (PG), pectate lyase (PL), peroxidase (POD) and polyphenol oxidase (PPO) [21,25,33-35,38,43]. Enzyme activity reduction by HPH is acquired by a combination of set temperature and pressure $[27,28]$. Inlet temperature and holding time of liquid at outlet temperature are very important [41,94,95], but pressure has the main impact on enzyme inactivation. Due to the mode of applied pressure, fluid-mechanical stresses are changing resulting in local cavitation, shear stress, collision, and turbulence, which affect the structure of the enzyme protein and its substrates [96,97]. As a result of dimensional configuration changes, the active site of enzymes lose their activity; moreover unfolded molecules have a tendency to aggregate, which also lead to their inactivation $[33,47,98]$. Aside from $\mathrm{HPH}$ processing parameters, specific characteristics of a particular enzyme are very important. In food, they occur in several forms (isozymes), which have various sensitivities to temperature, pressure and fluid-mechanical stresses [41,98]. Ripeness and matrix composition such as medium, presence of other proteins, sugars or salts and $\mathrm{pH}$ have an influence on thermo- and pressure-lability of enzymes [95,99].

Reported enzyme activity reduction by HPH varied but generally increased with preliminary warming of food to higher temperatures, increasing pressure and number of passes through the high pressure (HP)-valve $[95,98,100]$. Enzyme inactivation at $\mathrm{HPH}$-treated $(<200 \mathrm{MPa})$ juices was usually insufficient $[41,98]$. However, juice samples after treatment were more stable than the control samples [100,101]. UHPH processing $(\geq 200 \mathrm{MPa})$ was more effective in this matter. In some cases the obtained activity reduction was in the range of $90 \%-100 \%$ [24,41]. However, even UHPH treatment did not always guarantee sufficient enzymes inactivation in processed food $[95,100,102,103]$.

\section{Stability of Anthocyanins under Pressurization}

\subsection{High Pressure Processing (HPP)}

HPP preservation (at low, room and mild temperature) has a limited effect on anthocyanins degradation compared to thermal processing. Pelargonidin-3-glucoside and pelargonidin-3-rutinoside in raspberries and strawberries processed at $800 \mathrm{MPa}$ and $18-22^{\circ} \mathrm{C}$ for $15 \mathrm{~min}$ were stable [74], whereas 
some authors detected slight changes of anthocyanins in different red fruits and products obtained therefrom under HPP at mild and high temperatures (Table 2) $[64,76,104,105]$. Corrales et al. [106] and Barba et al. [107] reported insignificant changes of anthocyanins processed by HPP up to $600 \mathrm{MPa}$ at room temperature, whereas increasing the temperature up to $70{ }^{\circ} \mathrm{C}$ caused $25 \%$ losses of this pigments. This degradation was ca. $20 \%$ higher compared to the traditional thermal treatment at the same temperature, indicating that HPP coupled with higher temperatures accelerates anthocyanins decomposition [3]. These changes are mostly attributed to the conversion of monomeric anthocyanins to more condensed compounds during storage. This condensation reaction (Figure 3), induced by high pressure and/or temperatures, involves covalent association of anthocyanins with other flavonols or organic acids leading to the formation of a new pyran ring by cycloaddition. Anthocyanin condensation is responsible for the changes of colour i.e., in red wine during storage, by forming complexes of brown pigments [106]. It implies that high pressure should be used taking into account the negative influence of the synergistic effect of pressure and temperature. Further works on this technique should consider the calculation of heat dose as a function of time and process temperature.

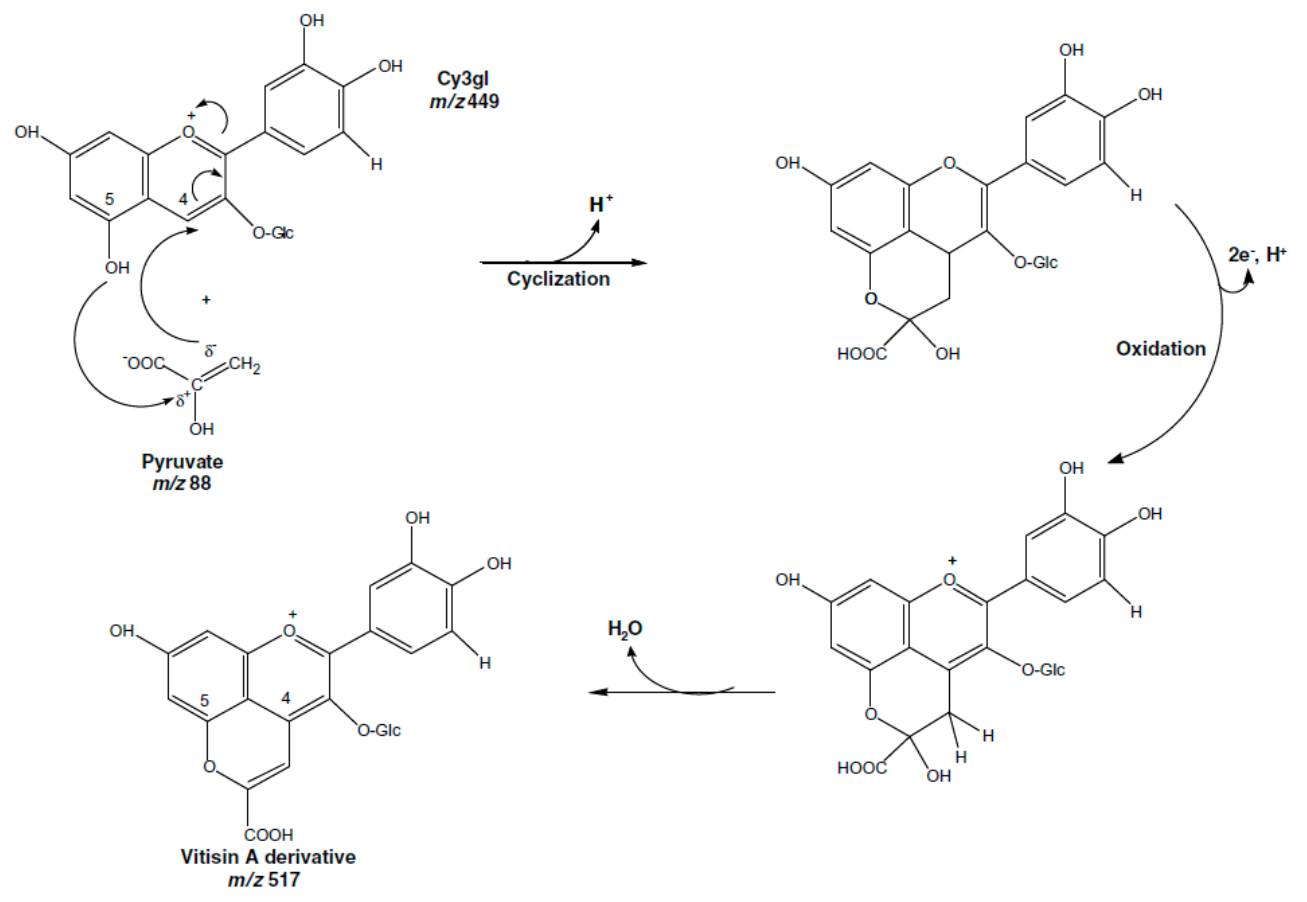

Figure 3. Condensation reaction of cyanidin-3-glucoside and pyruvate at $600 \mathrm{MPa}$ and $70{ }^{\circ} \mathrm{C}$ proposed by Corrales et al. [106].

The kinetics of anthocyanins degradation under HPP was investigated by Verbeyst et al. [7]. The authors described degradation of anthocyanins under thermal processing (TP) and HPP as being well described by a first-order kinetic model. They concluded that the higher temperature used under TP caused faster anthocyanins degradation. The reaction rate constant increased with increasing the pressure as well as the temperature rising under HPP. The kinetic rate constant noted for anthocyanins degradation generally increased with the increasing the pressure as well as temperature and ranged from 0.7 to $7.1 \times 10^{-2} \mathrm{~min}^{-1}$.

The activation energy ( $E_{\mathrm{a}}$-value) under high pressure coupled with temperature from 80 to $110{ }^{\circ} \mathrm{C}$ ranged from 58 to $63 \mathrm{~kJ} / \mathrm{mol}$ whereas this value calculated for TP at atmospheric pressure in the range from 95 to $130{ }^{\circ} \mathrm{C}$ was $94 \mathrm{~kJ} / \mathrm{mol}$. This means that the reaction rate constant at atmospheric pressure is less sensitive on temperature compared to reaction rate constants at similar temperatures under high pressure. The pressure dependence of the degradation rate constant was described by Eyring equations and expressed as activation volume $\left(V_{\mathrm{a}}\right.$-value). The values of the activation volume were 
negative, indicating an accelerating effect of pressure on the degradation of anthocyanins. As these values were small, the pressure dependence of the reaction rate constants was limited $[67,75]$.

Table 2. Effect of HPP on the anthocyanins stability.

\begin{tabular}{|c|c|c|c|c|}
\hline Source & Anthocyanin Studied & $\begin{array}{l}\text { Processing } \\
\text { Conditions }\end{array}$ & Effect & Reference \\
\hline Orange juice & Cy-3-glc & $\begin{array}{l}400-600 \mathrm{MPa} \text { for } \\
15 \mathrm{~min} \text { at } 20^{\circ} \mathrm{C}\end{array}$ & $99 \%$ retention of Cy-3-glc at $600 \mathrm{MPa}$ & [1] \\
\hline Pure anthocyanin & Cy-3-glc & $\begin{array}{l}200,600 \mathrm{MPa} \text { at } \\
25^{\circ} \mathrm{C} \text { and } 70^{\circ} \mathrm{C} \text { for } \\
\text { up to } 6 \mathrm{~h}\end{array}$ & $\begin{array}{l}\text { Insignificant changes at } 200 \mathrm{MPa} \text { and } 70{ }^{\circ} \mathrm{C}, 25 \% \text { loss } \\
\text { of Cy-3-glc after } 30 \mathrm{~min} \text { at } 600 \mathrm{MPa} \text { and } 70^{\circ} \mathrm{C} \text {, } \\
53 \% \text { loss after } 6 \mathrm{~h} \text { at the same parameters }\end{array}$ & [106] \\
\hline Blueberries & $\begin{array}{l}\text { Total anthocyanins } \\
\text { content }\end{array}$ & $\begin{array}{l}200-600 \mathrm{MPa}, \\
5-15 \mathrm{~min}, 25^{\circ} \mathrm{C}\end{array}$ & Insignificant changes & [107] \\
\hline Pomegranate juice & $\begin{array}{l}\text { Total anthocyanins } \\
\text { content }\end{array}$ & $\begin{array}{l}400-600 \mathrm{MPa}, \\
25-50^{\circ} \mathrm{C}, 5-10 \mathrm{~min}\end{array}$ & $\begin{array}{l}\text { Slight decrease progressing with increasing the } \\
\text { pressure and temperature }\end{array}$ & [108] \\
\hline $\begin{array}{l}\text { Strawberry and } \\
\text { wild berry } \\
\text { mousses, } \\
\text { pomegranate juice }\end{array}$ & $\begin{array}{l}\text { Total anthocyanins } \\
\text { content }\end{array}$ & $\begin{array}{l}500 \mathrm{MPa}, 50^{\circ} \mathrm{C}, \\
10 \mathrm{~min} \text { for mousses, } \\
400 \mathrm{MPa}, 25^{\circ} \mathrm{C}, \\
5 \mathrm{~min} \text { for juice }\end{array}$ & $\begin{array}{l}90 \% \text { retention in strawberry and wild berry mousses } \\
\text { and } 37 \% \text { of losses in pomegranate juice }\end{array}$ & [104] \\
\hline Strawberry pulps & $\begin{array}{l}\text { Cy-3-glc Pg-3-glc } \\
\text { Pg-3-rut }\end{array}$ & $\begin{array}{l}400-600 \mathrm{MPa}, \\
5-25 \mathrm{~min}, \\
\text { room temperature }\end{array}$ & $\begin{array}{l}\text { Insignificant changes of Cy-3-glc and Pg-3-glc, } \\
6 \% \text { loss of Pg-3-rut at } 400 \mathrm{MPa}, 10 \mathrm{~min}\end{array}$ & [65] \\
\hline $\begin{array}{l}\text { Strawberries } 3 \\
\text { cultivars }\end{array}$ & $\begin{array}{l}\text { Cy-3-glc Pg-3-glc } \\
\text { Pg-3-rut }\end{array}$ & $\begin{array}{l}600 \mathrm{MPa}, 20^{\circ} \mathrm{C}, \\
5 \mathrm{~min}\end{array}$ & $\begin{array}{l}20 \%-28 \% \text { losses depending on the strawberry } \\
\text { cultivar }\end{array}$ & [64] \\
\hline $\begin{array}{l}\text { Strawberry and } \\
\text { raspberry pastes } \\
\text { and juices }\end{array}$ & $\begin{array}{l}\text { Cy-3-glc Pg-3-glc } \\
\text { Pg-3-ara Cy-3-soph } \\
\text { Cy-3-rut }\end{array}$ & $\begin{array}{l}400-700 \mathrm{MPa}, \\
20-110^{\circ} \mathrm{C}, 20 \mathrm{~min}\end{array}$ & $\begin{array}{l}\text { Up to } 23 \% \text { changes at temperature below } 80^{\circ} \mathrm{C} \text { and } \\
\text { ca. } 80 \% \text { losses at temperature over } 80{ }^{\circ} \mathrm{C}\end{array}$ & [105] \\
\hline Strawberry paste & Cy-3-rut & $\begin{array}{l}200-700 \mathrm{MPa} \\
80-110^{\circ} \mathrm{C} \text {, up to } \\
50 \mathrm{~min}\end{array}$ & $\begin{array}{l}\text { Increasing the pressure accelerated degradation from } \\
1.7 \text { to } 2.4 \text { times (depending on the temperature), } \\
\text { increasing the temperature accelerated degradation } \\
\text { from } 5.0 \text { to } 6.0 \text { times (depending on the pressure) }\end{array}$ & [7] \\
\hline Strawberries & $\begin{array}{l}\text { Total anthocyanins } \\
\text { content }\end{array}$ & $\begin{array}{l}300-600 \mathrm{MPa}, \\
20-60^{\circ} \mathrm{C}, 2-10 \mathrm{~min}\end{array}$ & Insignificant changes & {$[62]$} \\
\hline Strawberry puree & $\begin{array}{l}14 \text { different } \\
\text { anthocyanins } \\
\text { compounds and their } \\
\text { condensed pigments }\end{array}$ & $\begin{array}{l}100-400 \mathrm{MPa}, \\
20-50^{\circ} \mathrm{C}, 15 \mathrm{~min}\end{array}$ & Insignificant changes & [109] \\
\hline Strawberry puree & $\begin{array}{l}\text { Cy-3-glc Pg-3-glc } \\
\text { Pg-3-rut }\end{array}$ & $\begin{array}{l}300-500 \mathrm{MPa}, \\
0-50{ }^{\circ} \mathrm{C}, 5-15 \mathrm{~min}\end{array}$ & $\begin{array}{l}8 \% \text { losses at } 0{ }^{\circ} \mathrm{C} \text { and } 15 \% \text { at } 50^{\circ} \mathrm{C} \text {, insignificant } \\
\text { influence of pressure and time }\end{array}$ & [13] \\
\hline Strawberry puree & $\begin{array}{l}\text { Cy-3-glc Pg-3-glc } \\
\text { Pg-3-rut }\end{array}$ & $\begin{array}{l}300-600 \mathrm{MPa}, \\
50^{\circ} \mathrm{C}, 15 \mathrm{~min}\end{array}$ & Up to $20 \%$ losses at $600 \mathrm{MPa}$ & [76] \\
\hline
\end{tabular}

The biggest advantages of HPP are generally insignificant changes of anthocyanins concentration at cold and room temperature under pressures up to $600 \mathrm{MPa}$. Unfortunately, for the efficient tissue enzyme inactivation mild heating is required. The increasing of temperature of HPP over $50{ }^{\circ} \mathrm{C}$ accelerates thermal degradation and condensation reaction of these pigments. Despite this, degradation of anthocyanins under HPP connected with moderate temperature is much lower compared to the traditional batch pasteurization.

\subsection{High Pressure Carbon Dioxide (HPCD)}

The impact of high pressure carbon dioxide on the quality of strawberry juice during the batch operation has been investigated by Marszałek et al. [85] at pressure, temperature and time up to $60 \mathrm{MPa}, 65{ }^{\circ} \mathrm{C}$ and $30 \mathrm{~min}$, respectively. In this study, they reported that no significant losses of anthocyanins were observed after $30 \mathrm{~min}$ of preservation at the temperature of $45^{\circ} \mathrm{C}$ and pressures of $30 \mathrm{MPa}$ and $60 \mathrm{MPa}$. Subsequent work of this team [86] expanded the range of conditions examined; time of preservation was $10-30 \mathrm{~min}$, temperature and pressure of the process were $35-65{ }^{\circ} \mathrm{C}$ and 10-60 MPa, respectively. The maximal reduction of anthocyanin content (ca. 10\%) was observed for the longest time and most harsh conditions; for the majority of combinations of parameters changes of anthocyanin concentrations was insignificant. 
Stability of anthocyanins in juice from blood oranges was tested by Fabroni et al. [110]. They applied three variants of the continuous process. Only the process carried out at $36{ }^{\circ} \mathrm{C}, 230 \mathrm{bar}$ and $0.770 \mathrm{~g}$ of carbon dioxide per $\mathrm{g}$ of sample showed significant degradation of pigments. Other variants using lower pressure (130 bar) and/or reduced $\mathrm{CO}_{2}$ /juice ratio had no significant impact.

The team led by Ramirez-Rodrigues [111] was investigating the impact of SCCD on Hibiscus sabdariffa beverage in a continuous process. Only one set of working conditions was tested: $30.6 \mathrm{MPa}, 8 \% \mathrm{CO}_{2}, 40{ }^{\circ} \mathrm{C}$ and treatment time $6.8 \mathrm{~min}$. They observed a small (ca. $3 \%$ ), but significant degradation of anthocyanins.

Zou et al. [112] were dealing with the effect of HPCD on mulberry juice. Samples were treated in a batch process for $10 \mathrm{~min}$ at a temperature of $55^{\circ} \mathrm{C}$ and pressure of $15 \mathrm{MPa}$. Surprisingly the increase of anthocyanin content of about $16 \%$ has been observed. The authors linked this phenomenon with a liberation of these compounds from the tissue, however this finding has not yet been confirmed by other researchers.

Del Pozo-Insfran et al. $[113,114]$ concentrated their work on the preservation of muscadine grape juice. They carried out the process continuously at pressure of $34.5 \mathrm{MPa}$ with $8 \%$ and $16 \%$ of $\mathrm{CO}_{2}$ (no information about temperature of process was provided). The preservation process has not changed the content of anthocyanins in a significant way in neither of the tested conditions.

The significant advantage of HPCD over HPP is the higher stability of anthocyanin pigments during process resulting from lowering of $\mathrm{pH}$ after application of carbon dioxide to the product. Moreover, the pressures used in this process is minimum tenfold lower than at HPP what can positively influenced on the condensation processes, limited under pressures below $100 \mathrm{MPa}$ [106].

\subsection{High Pressure Homogenization (HPH)}

It is well known that the presence of enzymes, oxygen, increasing $\mathrm{pH}$ and temperature, leads not only to the anthocyanins degradation, but can also cause their polymerization [92,115]. High pressure homogenization imposes mechanical stresses and then an inherent rise of temperature of the processed product $[27,101]$. Thus, there are indications that HPH and UHPH could cause anthocyanins content decrease. However Frank et al. [22] during HPH treatment at pressure 30-150 MPa of aqueous extract of bilberry, obtained almost constant anthocyanins concentration. Authors reported that in a solution of $\mathrm{pH}<4$, processed at the previously mentioned pressure range, no anthocyanins degradation due to fluid-mechanical stresses has been detected. Moreover, under these conditions anthocyanin molecules degradation was only temperature dependent. No thermal reduction was observed during high pressure treatment when rapid cooling after processing was applied. It was concluded that the $\mathrm{HPH}$ technique is a promising emerging method to provide best quality encapsulated and stabilized anthocyanin-rich emulsions.

Yu et al. [34] experiments with the UHPH treatment of mulberry juice also led to the finding that this kind of food preservation method can give good results in terms of anthocyanins retention. UHPH processing at $200 \mathrm{MPa}$ with one and three passes and ascorbic acid addition to the matrix did not cause significant reduction in the content of cyanidin 3-glucoside (Cy-3-glc) and cyanidin 3-rutinoside (Cy-3-rut). Ascorbic acid in this case was necessary to prevent the oxidation of anthocyanins in juice. When no ascorbic acid was added, action of the peroxide or polyphenoloxidase and dissolved oxygen took place, resulting in significant Cy-3-glc and Cy-3-rut reduction, 38.8\% and 33.2\%, respectively. Not only ascorbic acid inhibits anthocyanins oxidation. Yu et al. [34] observed the protective role of phenolic acids in mulberry juice, because they are more prone to oxidation than anthocyanins. After one-pass UHPH processing of fresh mulberry juice with no ascorbic acid added, all five identified phenolic acids decreased from $10 \%$ to $35 \%$. Further reduction to $30 \%-40 \%$ of initial content was observed when UHPH processing was continued to three passes, while anthocyanins content showed no further reductions.

The research of Karacam et al. [101] on the influence of cooling system during HPH on anthocyanins retention showed how important is this process. The authors subjected strawberry 
juice to HPH processing at 60 and $100 \mathrm{MPa}$ with two or five passes. Cooling was not used after HP-valve nor after completion of the entire procedure. After 2 and 5 passes of juice through the homogenizer at $100 \mathrm{MPa}$, the final recorded temperature was 43.3 and $56.6^{\circ} \mathrm{C}$, respectively (data not shown for $60 \mathrm{MPa}$ ). Raised temperatures gave colour changes of the samples, i.a. drop of $a^{*}$ value (redness) what was connected with the reduction of anthocyanins level. At $100 \mathrm{MPa}$ redness of juice decreased from 2 passes to 5 passes, interpreted as degradation of anthocyanins which are compounds mainly responsible for the red colour of strawberries. According to the authors the reduction of anthocyanins occurred as a result of elevated temperature and also may be related to the Maillard reaction, which products react with anthocyanins, thereby accelerating their degradation.

Ultra high pressure processing should be considered as a good pretreatment method of fruit puree containing anthocyanins before spray drying. According to the published results, homogenization of raspberry puree with $10 \%$ of water solution of arabic gum at pressure of $207 \mathrm{MPa}$ with five passes and cooled coil gave excellent particle comminution and better coating of particles by arabic gum matrix, which manifested as better anthocyanins retention in encapsulated powders than in powders obtained without UHPH processing. The most important observation is that UHPH technique allowed to extract more anthocyanins from raspberry puree than a homogenizator working at ambient pressure [116].

Negative factor of $\mathrm{HPH}$ is the temperature increasing during homogenization which can influenced on the anthocyanins stability. The application of cooling system is generally enough for maintain temperature during HPH. There is no prove on the influence of the homogenization process on the degradation of anthocyanins. The biggest advantages of this process is the continuous operation mode and thus much higher efficiency compared to other techniques.

\section{Traditional Thermal Processing (TP) vs. Pressure Techniques}

Table 3 summarizes recently published results concerning the impact of temperature on fruit anthocyanins. Basically, TP preservation at temperature from 70 to $140{ }^{\circ} \mathrm{C}$ has a much greater effect on anthocyanins degradation compared to high pressure techniques. Even as short processing time as 2 min of thermal treatment of strawberry pulp at $70{ }^{\circ} \mathrm{C}$ caused significant decrease of total content of anthocyanins (20\%) [65]. Increasing of temperature and time of treatment led to higher degradation of the pigments. To improve thermal stability of anthocyanins different approaches have been used, including the arabic gum addition to anthocyanins solutions. Arabic gum in an amount of $10 \mathrm{mg} / \mathrm{mL}$ increased the half-life of anthocyanins by 2.0 and 1.35 times at 80 and $126^{\circ} \mathrm{C}$, respectively [117].

Table 3. Effect of thermal processing on the anthocyanins stability.

\begin{tabular}{|c|c|c|c|c|}
\hline Source & Anthocyanin Studied & $\begin{array}{l}\text { Processing } \\
\text { Conditions }\end{array}$ & Effect & Reference \\
\hline Pure anthocyanin & cyanidin-3-glucoside & $70^{\circ} \mathrm{C}$ for up to $6 \mathrm{~h}$ & $\begin{array}{c}5 \% \text { loss after } 30 \mathrm{~min}, \\
25 \% \text { loss after } 6 \mathrm{~h}\end{array}$ & [106] \\
\hline Strawberry pulp & $\begin{array}{l}\text { cyanidin-3-glucoside, } \\
\text { pelargonidin-3-glucoside, } \\
\text { pelargonidin-3-rutinoside }\end{array}$ & $70^{\circ} \mathrm{C}, 2 \mathrm{~min}$ & $20 \%$ loss of total anthocyanins & [65] \\
\hline Strawberries & $\begin{array}{l}\text { cyanidin-3-glucoside, } \\
\text { pelargonidin-3-glucoside, } \\
\text { pelargonidin-3-rutinoside }\end{array}$ & $88^{\circ} \mathrm{C}, 2 \mathrm{~min}$ & $22 \%-25 \%$ loss of total anthocyanins & {$[64]$} \\
\hline $\begin{array}{l}\text { Strawberry and } \\
\text { raspberry pastes } \\
\text { and juices }\end{array}$ & $\begin{array}{l}\text { cyanidin-3-glucoside, } \\
\text { pelargonidin-3-glucoside, } \\
\text { pelargonidin-3-arabinoside }\end{array}$ & $80-140{ }^{\circ} \mathrm{C}, 20 \mathrm{~min}$ & $\begin{array}{l}\text { Significant degradation of all } \\
\text { monomer, at } 140^{\circ} \mathrm{C} \text { almost total } \\
\text { degradation of anthocyanins }\end{array}$ & [105] \\
\hline Strawberry paste & cyanidin-3-glucoside & $\begin{array}{l}95-130{ }^{\circ} \mathrm{C} \text {, } \\
\text { up to } 50 \mathrm{~min}\end{array}$ & $\begin{array}{c}\text { Increasing the temperature from } 95 \text { to } \\
130^{\circ} \mathrm{C} \text { increased } \mathrm{Cy}-3-\mathrm{Glc} \\
\text { degradation } 15 \times\end{array}$ & [7] \\
\hline Strawberry puree & $\begin{array}{l}\text { cyanidin-3-glucoside, } \\
\text { pelargonidin-3-glucoside, } \\
\text { pelargonidin-3-rutinoside }\end{array}$ & $90^{\circ} \mathrm{C}, 15 \mathrm{~min}$ & $43 \%$ losses & [13] \\
\hline
\end{tabular}




\section{Influence of High Pressure on the Anthocyanin Stability during Storage}

\subsection{High Pressure Processing (HPP)}

Anthocyanins present in fruit and vegetable products subjected to HPP are not stable during storage. The changes of these pigments during storage occur through non-enzymatic as well as enzymatic reactions, due to partial tissue enzymes and microorganisms activity (Table 4). The 7 days storage studies at 20 and $30{ }^{\circ} \mathrm{C}$ of blackcurrants pressurized at 200-800 MPa for $15 \mathrm{~min}$ at room temperature showed that cyanidin-3-rutinoside and delphinidin-3-rutinoside were degraded, whereas cold storage at $4{ }^{\circ} \mathrm{C}$ did not influence anthocyanins [118].

The mechanism of enzymatic degradation of anthocyanins, presented in Figure 2, is connected with the incomplete inactivation of tissue enzymes like $\beta$-GLC, PPO and POD [74,119]. The HPP inactivation of PPO at $800 \mathrm{MPa}$ at room temperature for 15 min was linked with the stability of pelargonidin-3-glucozide and pelargonidin-3-rutinoside during storage [74]. The significant role of $\beta$-GLC and POD in anthocyanin degradation during storage was confirmed by other authors $[52,120]$. Degradation of cyanidin-3-glucoside and cyanidin-3-sophoroside during prolonged storage (9 days) of pressurized raspberries were connected with a lower degree of inactivation of these enzymes [106].

Substrate specificity of $\beta$-glucosidase plays a significant role at the first step of anthocyanins degradation. Zabetakis et al. [119] noted higher loss of pelargonidin-3-glucoside compared with pelargonidin-3-rutinoside in HPP treated strawberries, at the same level of $\beta$-GLC residual activity, because of greater affinity of this enzyme towards glucose compared to rutinose. Enzyme degradation of anthocyanin pigments by $\beta$-GLC is mainly due to the loss of glucose leading to the formation of anthocyanidins (aglycon) affecting the red colour [3,52,84]. A similar trend was also described by Gimenez et al. [121] in strawberry jams.

Ascorbic acid is one of the important factors influencing the stability on anthocyanins pigments. This acid, apart from being an antioxidant, plays a significant role in the acceleration of anthocyanins degradation [118]. Ascorbic acid and anthocyanins diminish simultaneously in stored fruit products. The degradation of anthocyanins by ascorbic acid is induced indirectly by hydrogen peroxide formation during oxidation, therefore supplying a substrate for enzymatic reaction catalyzed by POD [1].

Anthocyanin losses can be reduced by storing of HPP treated samples at low temperatures.

Table 4. Effect of HPP on the anthocyanins stability during storage.

\begin{tabular}{|c|c|c|c|c|}
\hline Source & Anthocyanin Studied & $\begin{array}{l}\text { Processing/Storage } \\
\text { Conditions }\end{array}$ & Effect & Reference \\
\hline Raspberries & Cy-3-glc Cy-3-Soph & $\begin{array}{l}200-800 \mathrm{MPa}, 18-22{ }^{\circ} \mathrm{C}, \\
15 \mathrm{~min} \text {, Storage : } 4,20,30{ }^{\circ} \mathrm{C} \\
\text { for } 9 \text { days }\end{array}$ & $\begin{array}{l}\text { Greater stability at } 800 \mathrm{MPa} \\
\text { for } \mathrm{Cy}-3 \text {-glc and } \mathrm{Cy}-3-\mathrm{Soph} \\
\text { at } 4^{\circ} \mathrm{C} \text { of storage }\end{array}$ & [120] \\
\hline Blackcurrants & Dp-3-rut Cy-3-rut & $\begin{array}{l}200-800 \mathrm{MPa}, 18-22{ }^{\circ} \mathrm{C}, \\
15 \mathrm{~min} \text {, Storage: } 5,20,30{ }^{\circ} \mathrm{C} \\
\text { for } 7 \text { days }\end{array}$ & $\begin{array}{l}\text { Greater stability at } 600 \mathrm{MPa} \\
\text { for Cy-3-rut and } 800 \mathrm{MPa} \text { for } \\
\text { Dp-3-rut at } 5^{\circ} \mathrm{C} \text { of storage }\end{array}$ & [118] \\
\hline $\begin{array}{l}\text { Muscadine grape } \\
\text { juice }\end{array}$ & $\begin{array}{l}\text { Delphinidin-3, } \\
\text { 5-diglucoside, } \\
\text { Petunidin-3,5-diglucoside, } \\
\text { Peonidin-3,5-diglucoside, } \\
\text { Malvidin-3,5-diglucoside }\end{array}$ & $\begin{array}{l}400 \text { and } 550 \mathrm{MPa} \text { for } 15 \mathrm{~min} \text {, } \\
\text { Storage: } 25^{\circ} \mathrm{C} \text { for } 21 \text { days }\end{array}$ & $\begin{array}{l}28 \%-34 \% \text { losses at } 25^{\circ} \mathrm{C} \text { of } \\
\text { storage }\end{array}$ & [122] \\
\hline Orange juice & Cy-3-glc & $\begin{array}{l}400-600 \mathrm{MPa} \text { for } 15 \mathrm{~min} \text { at } \\
20^{\circ} \mathrm{C} \text {, Storage : } 4 \text { and } 20^{\circ} \mathrm{C} \\
\text { for } 10 \text { days }\end{array}$ & $\begin{array}{l}93 \% \text { and } 89 \% \text { retention at } \\
600 \mathrm{MPa} \text { in juice stored at } 4 \\
\text { and } 20{ }^{\circ} \mathrm{C}\end{array}$ & {$[1]$} \\
\hline $\begin{array}{l}\text { Strawberry and } \\
\text { wild berry } \\
\text { mousses, } \\
\text { pomegranate juice }\end{array}$ & $\begin{array}{l}\text { Total anthocyanins } \\
\text { content }\end{array}$ & $\begin{array}{l}500 \mathrm{MPa}, 50^{\circ} \mathrm{C}, 10 \mathrm{~min} \text { for } \\
\text { mousses, } 400 \mathrm{MPa}, 25^{\circ} \mathrm{C}, \\
5 \text { min for juice, Storage: } 4 \text { and } \\
25^{\circ} \mathrm{C} \text { for } 72 \text { days }\end{array}$ & $\begin{array}{l}35 \%-37 \% \text { of losses for both } \\
\text { products }\end{array}$ & [104] \\
\hline Strawberries & $\begin{array}{c}\text { Cy-3-glc Pg-3-glc } \\
\text { Pg-3-rut }\end{array}$ & $\begin{array}{l}600 \mathrm{MPa}, 20^{\circ} \mathrm{C}, 5 \mathrm{~min}, \\
\text { Storage: } 4^{\circ} \mathrm{C} \text { for } 3 \text { months }\end{array}$ & $\begin{array}{l}19 \%-25 \% \text { retention after } \\
3 \text { month of storage }\end{array}$ & {$[64]$} \\
\hline
\end{tabular}


Table 4. Cont.

\begin{tabular}{|c|c|c|c|c|}
\hline Source & Anthocyanin Studied & $\begin{array}{l}\text { Processing/Storage } \\
\text { Conditions }\end{array}$ & Effect & Reference \\
\hline $\begin{array}{l}\text { Strawberry cloudy } \\
\text { and clear juices }\end{array}$ & $\begin{array}{l}\text { Cy-3-glc Pg-3-glc } \\
\text { Pg-3-rut }\end{array}$ & $\begin{array}{l}600 \mathrm{MPa} \text {, room temperature, } \\
4 \mathrm{~min} \text {, Storage: } 4 \text { and } 25^{\circ} \mathrm{C} \text { for } \\
6 \text { months }\end{array}$ & $\begin{array}{l}30 \% \text { and } 7 \% \text { losses in cloudy } \\
\text { and clear juices }\end{array}$ & [123] \\
\hline Strawberries & Pg-3-glc Pg-3-rut & $\begin{array}{l}200-800 \mathrm{MPa}, 18-22{ }^{\circ} \mathrm{C}, \\
15 \text { min, Storage: } 4,20,30{ }^{\circ} \mathrm{C} \\
\text { for } 9 \text { days }\end{array}$ & $\begin{array}{l}\text { Greatest stability after } \\
\text { processing at } 800 \mathrm{MPa} ; \\
\text { storage at } 4{ }^{\circ} \mathrm{C}\end{array}$ & [119] \\
\hline Strawberry puree & $\begin{array}{c}\text { Cy-3-glc Pg-3-glc } \\
\text { Pg-3-rut }\end{array}$ & $\begin{array}{l}300-600 \mathrm{MPa}, 50{ }^{\circ} \mathrm{C}, 15 \mathrm{~min} \text {, } \\
\text { Storage: } 6^{\circ} \mathrm{C} \text { for } 4 \text { and } \\
28 \text { weeks for } 300 \text { and } 600 \mathrm{MPa} \text {, } \\
\text { respectively }\end{array}$ & $\begin{array}{l}\text { fastest degradation after } \\
\text { processing at } 600 \mathrm{MPa} \\
\text { compared to } 300 \mathrm{MPa} \text {, } \\
\text { half-life: } 62 \text { and } 86 \text { days, } \\
\text { respectively for } 600 \text { and } \\
300 \mathrm{MPa} \text {, the lowest stability } \\
\text { of Pg-3-rut }\end{array}$ & {$[76]$} \\
\hline Strawberry puree & $\begin{array}{c}\text { Cy-3-glc Pg-3-glc } \\
\text { Pg-3-rut }\end{array}$ & $\begin{array}{l}500 \mathrm{MPa}, 50^{\circ} \mathrm{C}, 15 \mathrm{~min}, \\
\text { Storage: } 6^{\circ} \mathrm{C} \text { for } 12 \text { weeks }\end{array}$ & $\begin{array}{l}73 \% \text { degradation of TCA, the } \\
\text { lowest stability of Pg-3-rut }\end{array}$ & [124] \\
\hline Strawberry & $\begin{array}{l}\text { Total anthocyanins } \\
\text { content }\end{array}$ & $\begin{array}{l}400 \mathrm{MPa} \text {, room temperature, } \\
5 \mathrm{~min} \text {, Storage: } 4 \text { and } 25^{\circ} \mathrm{C} \text { for } \\
45 \text { days }\end{array}$ & $\begin{array}{l}33 \% \text { and } 57 \% \text { degradation in } \\
\text { samples stored at } 4 \text { and } \\
25{ }^{\circ} \mathrm{C}\end{array}$ & [125] \\
\hline Bayberry juice & Cy-3-glc & $\begin{array}{l}400-600 \mathrm{MPa} \text {, room } \\
\text { temperature, } 10 \mathrm{~min} \text {, Storage: } \\
4 \text { and } 25^{\circ} \mathrm{C} \text { for } 25 \text { days }\end{array}$ & $\begin{array}{l}8 \% \text { degradation in samples } \\
\text { stored at } 4 \text { and significantly } \\
\text { higher in samples stored at } \\
25^{\circ} \mathrm{C}\end{array}$ & [126] \\
\hline Pomegranate juice & $\begin{array}{l}\text { Total anthocyanins } \\
\text { content }\end{array}$ & $\begin{array}{l}300-400 \mathrm{MPa} \text {, room } \\
\text { temperature, } 2.5-25 \mathrm{~min} \text {, } \\
\text { Storage: } 4{ }^{\circ} \mathrm{C} \text { for } 90 \text { days }\end{array}$ & $25 \%$ degradation & [127] \\
\hline Aronia juice & - & $\begin{array}{l}200-600 \mathrm{MPa} \text {, room } \\
\text { temperature, } 15 \mathrm{~min} \text {, Storage } \\
4{ }^{\circ} \mathrm{C} \text { for } 80 \text { days }\end{array}$ & $\begin{array}{l}\text { Ca. } 40 \% \text { degradation at } \\
600 \mathrm{MPa}\end{array}$ & [128] \\
\hline
\end{tabular}

Changes in the content of the anthocyanin pigments in strawberry puree during storage, described as the kinetic rate constant, were previous studied by Marszałek et al. [76]. Authors showed that kinetics rate constant generally increased with increasing the pressure of process from 300 to $600 \mathrm{MPa}$ and ranged from 0.38 to $2.17 \times 10^{-2}$ days $^{-1}$ for sample stored at $6{ }^{\circ} \mathrm{C}$. Authors connected this phenomenon with higher PPO residual activity at higher pressure which significalntly influence on the anthocyanins stability during storage. On the other hand Cao et al. [123] noted higher kinetic rate constant range from 0.056 to 0.505 months $^{-1}$, calculated for anthocyanins in strawberry juice preserved at $600 \mathrm{MPa}, 4 \mathrm{~min}$ and stored at cold and room temperature, respectively.

Different hypothesis have been postulated on the mechanism of degradation of anthocyanins during storage. The reduction of anthocyanins content in most cases was probably connected with oxidation processes, condensation with phenolic compounds, polymerization and enzyme degradation [105,125,127]. Garcia-Palazon et al. [74] observed that two different pelargonidins in raspberry were stable during storage, when PPO was inactivated. Zabetakis et al. [119] related anthocyanins degradation during storage with specificity of some substrates of $\beta$-glucosidase and anthocyanins. Cao et al. [123] found a loss of anthocyanins in cloudy strawberry juices, which was possibly due to the higher concentration of oxygen absorbed in pulp particles promoting the degradation. The stability of anthocyanins was also influenced by other fruit components, for instance by products of degradation of ascorbic acid and monosaccharides may accelerate anthocyanins degradation $[109,127]$. It is well known that during storage in some pressurized food enzymatic browning appears, but it is also observed that the addition of antioxidant such as ascorbic acid inhibits the browning effect and the activity of some enzymes such as POD is reduced [109]. Moreover, higher temperature of storage significantly accelerates all biochemical reaction. HPP facilitates the enzymatic and non-enzymatic reactions, because due to cell disruption substrates, ions and enzymes located in different compartments in the cell are liberated and can interact with each other. 
Similarly to enzymatic browning, the non-enzymatic Maillard reaction is known to be affected by many factors, including temperature and $\mathrm{pH}$ [109].

\subsection{High Pressure Carbon Dioxide (HPCD)}

In the research on strawberry juice led by Marszałek et al. [85] samples were pressurized with carbon dioxide in a supercritical state for $30 \mathrm{~min}$ at $45^{\circ} \mathrm{C}$ in 30 and $60 \mathrm{MPa}$. The experiments proved first order kinetics of anthocyanin degradation. Established half-life values were 22.4-28.6 days for $30 \mathrm{MPa}$ treatment and 26.4-32.7 days for $60 \mathrm{MPa}$ treatment. Changes in the content of the anthocyanin pigments in strawberry juice during storage after HPCD treatment, described as the kinetic rate constant, were reported by Marszałek et al. [85]. Authors showed that kinetics rate constant of decomposition of each monomer in strawberry juice stored at $6{ }^{\circ} \mathrm{C}$ increased from 0.021 to 0.031 days ${ }^{-1}$ with increasing pressure from 30 to $60 \mathrm{MPa}$. This phenomenon was connected with higher POD residual activity noted in juices treated by the lower pressure in HPCD treatment.

Storage research on blood orange juice treated with SCCD at 13 and $23 \mathrm{MPa}$ and $36^{\circ} \mathrm{C}$ has shown that anthocyanins were stable for 20 days. Subsequent degradation was connected with a rapid microbial growth in samples rather than with the activity of tissue enzymes [110].

Stability of anthocyanins in extracts of Hibiscus sabdariffa preserved by HPCD was comparable with non-treated samples; 14 weeks of storage caused less than a $10 \%$ decrease of the amount of pigments [111]. It should be noted that due to the method of food products preparation the activity of the endogenous enzyme is suspected to be negligible.

The research by Zou et al. [112] on mulberry beverage stored after treatment with HPCD at $55^{\circ} \mathrm{C}$, $15 \mathrm{MPa}$ for $10 \mathrm{~min}$ showed significant losses of anthocyanins after 7 days at $25^{\circ} \mathrm{C}$ and after 14 days at $4{ }^{\circ} \mathrm{C}$, however no numerical values have been provided. The degradation of anthocyanins has been associated with the activity of polyphenol oxidases. The stability of anthocyanins found in muscadine grape juice treated by HPCD and stored for four weeks at $4{ }^{\circ} \mathrm{C}$ with no residual activity of this enzyme were 4.5 fold higher compared with juice with active enzyme [88]. Juices preserved by HPCD in the presence of oxidoreductases offered appreciable retention of the phytochemical variables that was attributed with decrease in dissolved oxygen and protection of non-anthocyanin phenolic compounds during refrigerated storage [88]. Some studies have shown that reversible changes in protein structure can occur following enzyme inactivation and may be influenced by processing conditions such as pressure, carbon dioxide, temperature, holding time and the subsequent conditions of storage [88]. Temperature of storage plays a crucial role in the rate of anthocyanins degradation during storage, since low temperature slow enzymatic reactions.

\subsection{High Pressure Homogenization (HPH)}

According to the authors best knowledge, there are no publications on the stability of anthocyanins as well as their kinetics of degradation in fruit and vegetable products during storage after HPH or UHPH processing.

\section{Conclusions}

The pressure-based food preservation methods are an interesting alternative for the traditional thermal processing techniques like pasteurization. They are a response for increasing customers demand on a microbiologically safe food with a high nutritional value and superior sensory quality. Anthocyanins are exceptionally important in this context, because they are both biologically active compounds and the main pigments for many fruits and vegetables, being at the same time quite heat-sensitive.

The HPP processing is already industrially used for preservation of various food groups, however it is the least potent among the three discussed pressure techniques in inactivation of tissue enzymes. Use of HPCD allows minimizing losses of anthocyanins during processing and storage, however application of carbon dioxide leads to the major technical problems; additionally carbon dioxide can 
significantly alter sample properties such as acidity. HPH is a relatively young method and its use is so far limited to the laboratory trials. Despite all their flaws high pressure techniques can be advantageous against heat treatment in retention of health promoting compounds such as anthocyanins.

Although the mechanisms involved in degradation of anthocyanins are complex, the whole process can accurately be described by a first order reaction kinetics. Literature data show that activation energy is not dependent on pressure of HPP process, however its values are significantly lower those calculated for TP.

The knowledge about impact of high pressures on the tissue enzymes is so far limited to the empirical observations of their activity. For the better description of phenomena occurring during pressurization further research, including the changes in tertiary and quaternary structures of proteins during processing, should be performed. According to authors best knowledge there are limited number of publications about influence of HPCD and HPH techniques on the anthocyanins and tissue enzymes kinetics degradation.

The research on the effects of high-pressure food processing methods should be continued as industry is constantly implementing these techniques, which can in many cases be a good substitute to traditional thermal preservation.

Acknowledgments: This paper was prepared within the Project number 2015/17/D/NZ9/02079 of the National Science Centre, Poland.

Conflicts of Interest: The authors declare no conflict of interest.

\section{References}

1. Torres, B.; Tiwari, B.K.; Partas, A.; Cullen, P.J.; Brunton, N.; O'Donnel, C.P. Stability of anthocyanins and ascorbic acid of high pressure processes blood orange juice during storage. Innov. Food Sci. Emerg. 2011, 12, 93-97. [CrossRef]

2. Oren-Shamir, M. Does anthocyanins degradation play a significant role in determining pigment concentration in plants? Plant Sci. 2009, 177, 310-316. [CrossRef]

3. Tiwari, B.K.; O'Donnell, C.P.; Cullen, P.J. Effect of non-thermal processing technologies on the anthocyanin content of fruit juices. Trends Food Sci. Technol. 2009, 20, 137-145. [CrossRef]

4. Patras, A.; Brunton, N.P.; O'Donnell, C.; Tiwari, B.K. Effect of thermal processing on anthocyanin stability in foods; mechanisms and kinetics of degradation. Trends Food Sci. Technol. 2010, 21, 3-11. [CrossRef]

5. McDougall, G.J.; Fyffe, S.; Dobson, P.; Stewart, D. Anthocyanins from red wine-Their stability under simulated gastrointestinal digestion. Phytochemistry 2005, 66, 2540-2548. [CrossRef] [PubMed]

6. Wrolstad, R.E.; Durst, R.W.; Jungmin, L. Tracking color and pigment changes in anthocyanin products. Trends Food Sci. Technol. 2005, 16, 423-428. [CrossRef]

7. Verbeyst, L.; Oey, I.; Plancken, V.I.; Hendrickx, M.; Loey, A. Kinetic study on the thermal and pressure degradation of anthocyanins in strawberries. Food Chem. 2010, 123, 269-274. [CrossRef]

8. Barba, F.J.; Terefe, N.S.; Buckow, R.; Knorr, D.; Orlien, V. New opportunities and perspectives of high pressure treatment improve health and safety attributes of foods. Food Res. Int. 2015, 77, 725-742. [CrossRef]

9. Mazza, G.; Kay, C.D.; Cottrell, T.; Holub, B.J. Absorption of anthocyanins from blueberries and serum antioxidant status in human subjects. J. Agric. Food Chem. 2002, 50, 7731-7737. [CrossRef] [PubMed]

10. Bitsch, I.; Janssen, M.; Netzel, M.; Strass, G.; Frank, T. Bioavailability of anthocyanidin-3-glycosides following consumption of elderberry extract and blackcurrant juice. Int. J. Clin. Pharm. Ther. 2004, 42, 293-300. [CrossRef]

11. Bub, A.; Watzl, B.; Heeb, D.; Rechkemmer, G.; Briviba, K. Malvidin-3-glucoside bioavailability in humans after ingestion of red wine, dealcoholised red wine and red grape juice. Eur. J. Nutr. 2001, 40, 113-120. [CrossRef] [PubMed]

12. Frank, T.; Netzel, M.; Strass, G.; Bitsch, I. Bioavailability of anthocyanidin-3-glucosides following consumption of red wine and red grape juice. Can. J. Physiol. Pharm. 2003, 81, 423-435. [CrossRef] [PubMed] 
13. Marszałek, K.; Mitek, M.; Skapska, S. The effect of thermal pasteurization and high pressure processing at cold and mild temperatures on the chemical compositions, microbial and enzyme activity in strawberry puree. Innov. Food Sci. Emerg. 2015, 27, 48-56. [CrossRef]

14. Jimenez-Sánchez, C.; Lozano-Sánchez, J.; Seguera-Carretero, A.; Fernández-Gutiérrez, A. Alternatives to conventional thermal treatments in fruit-juice processing. Part 1: Techniques and applications. Crit. Rev. Food Sci. Nutr. 2017, 57, 501-523. [CrossRef] [PubMed]

15. Jimenez-Sánchez, C.; Lozano-Sánchez, J.; Seguera-Carretero, A.; Fernández-Gutiérrez, A. Alternatives to conventional thermal treatments in fruit-juice processing. Part 2: Effect on composition. Phytochemical content, and physicochemical, rheorogical, and organoleptic properties of fruit juices. Crit. Rev. Food Sci. Nutr. 2017, 57, 637-652. [CrossRef] [PubMed]

16. Butz, P.; Garcia, F.; Lindauer, R.; Dietrich, S.; Bognar, A.; Tauscher, B. Influence of ultra-high pressure processing on fruit and vegetable products. J. Food Eng. 2003, 56, 233-236. [CrossRef]

17. Valdamidis, V.P.; Graham, W.D.; Beattie, A.; Linton, M.; McKay, A.; Fearon, A.M.; Petterson, M.F. Defining the stability interfaces of apple juice: Implications on the optimisation and design of high hydrostatic pressure treatment. Innov. Food Sci. Emerg. 2010, 10, 396-404. [CrossRef]

18. Deuel, C.L.; Plotto, A. Strawberries and Raspberries. In Processing Fruits: Science and Technology, 2nd ed.; Barrett, D.M., Somogyi, L.P., Ramaswamy, H.S., Eds.; CRC Press: Boca Raton, FL, USA, 2005.

19. Oey, I.; Lille, M.; van Loey, A.; Hendrickx, M. Effect of high pressure processing on colour, texture and flavour of fruit and vegetable-based food products. Trends Food Sci. Technol. 2008, 19, 320-328. [CrossRef]

20. Damar, S.; Balaban, M.O. Review of dense phase $\mathrm{CO}_{2}$ technology: Microbial and enzyme inactivation, and effects on food quality. J. Food Sci. 2006, 71, R1-R11. [CrossRef]

21. Betoret, E.; Betoret, N.; Carbonell, J.V.; Fito, P. Effects of pressure homogenization on particle size and the functional properties of citrus juices. J. Food Eng. 2009, 92, 18-23. [CrossRef]

22. Frank, K.; Köhler, K.; Schuchmann, H.P. Stability of anthocyanins in high pressure homogenisation. Food Chem. 2012, 130, 716-719. [CrossRef]

23. Suárez-Jacobo, Á.; Rüfer, C.E.; Gervilla, R.; Guamis, B.; Roig-Sagués, A.X.; Saldo, J. Influence of ultra-high pressure homogenisation on antioxidant capacity, polyphenol and vitamin content of clear apple juice. Food Chem. 2011, 127, 447-454. [CrossRef] [PubMed]

24. Suárez-Jacobo, Á.; Saldo, J.; Rüfer, C.E.; Guamis, B.; Roig-Sagués, A.X.; Gervilla, R. Aseptically packaged UHPH-treated apple juice: Safety and quality parameters during storage. J. Food Eng. 2012, 109, 291-300. [CrossRef]

25. Velázquez-Estrada, R.M.; Hernández-Herrero, M.M.; Rüfer, C.E.; Guamis-López, B.; Roig-Sagués, A.X. Influence of ultra-high-pressure homogenization processing on bioactive compounds and antioxidant activity of orange juice. Innov. Food Sci. Emerg. 2013, 18, 89-94. [CrossRef]

26. Toro-Funes, N.; Bosch-Fusté, J.; Veciana-Nogués, M.T.; Vidal-Carou, M.C. Changes of isoflvones and protein quality in soymilk pasteurized by ultra-high-pressure homogenisation throughout storage. Food Chem. 2014, 162, 47-53. [CrossRef] [PubMed]

27. Dumay, E.; Chevalier-Lucia, D.; Picart-Palmade, L.; Benzaria, A.; Gràcia-Julià, A.; Blayo, C. Technological aspects and potential applications of ultra-high-pressure homogenisation. Trends Food Sci. Technol. 2013, 31, 13-26. [CrossRef]

28. Cortés-Munoz, M.; Chevalier-Lucia, D.; Dumay, E. Characteristics of submicron emulsions prepared by ultra-high pressure homogenisation: Effect of chilled or frozen storage. Food Hydrocoll. 2009, 23, 640-654. [CrossRef]

29. Hayes, M.G.; Kelly, A.L. High-pressure homogenisation of raw whole bovine milk effects on fat globule size and other properties. J. Dairy Res. 2003, 70, 297-305. [CrossRef] [PubMed]

30. Kiełczewska, K.; Kruk, A.; Czerniewicz, M.; Haponiuk, E. Effects of high-pressure homogenisation on the physicochemical properties of milk with various fat concentrations. Pol. J. Food Nutr. Sci. 2006, 56, 91-94.

31. Vachon, J.F.; Khedar, E.E.; Giasson, J.; Pasquin, P.; Fliss, I. Inactivation of foodborne pathogens in milk using dynamic high pressure. J. Food Prot. 2002, 65, 345-352. [CrossRef] [PubMed]

32. Lanciotti, R.; Vannini, L.; Patrignani, F.; Lucci, L.; Valliceli, M.; Ndagijimana, M.; Guerzoni, M.E. Effect of high pressure homogenisation of milk on cheese field and microbiology, lipolysis and proteolysis during ripening of Caciotta cheese. J. Dairy Res. 2006, 73, 216-226. [CrossRef] [PubMed] 
33. Calligaris, S.; Foschia, M.; Bartolomeoli, I.; Maifreni, M.; Manzocco, L. Study on the applicability of high-pressure homogenization for the production of banana juices. LWT Food Sci. Technol. 2012, 45, 117-121. [CrossRef]

34. Yu, Y.; Xu, Y.; Wu, J.; Xiao, G.; Fu, M.; Zhang, Y. Effect of ultra-high-pressure homogenization processing on phenolic compounds, antioxidant capacity and anti-glucosidase of mulberry juice. Food Chem. 2014, 153, 114-120. [CrossRef] [PubMed]

35. Augusto, P.E.D.; Ibarz, A.; Cristianini, M. Effect of high pressure homogenization (HPH) on the rheological properties of tomato juice: Time-dependent and steady-state shear. J. Food Eng. 2012, 111, 570-579. [CrossRef]

36. Patrignani, F.; Vannini, L.; Leroy, S.; Kamdem, S.; Lancotti, R.; Guerzoni, E.M. Effect of high-pressure homogenization on Saccharomyces cerevisiae inactivation and physic-chemical features in apricot and carrot juices. Int. J. Food Microbiol. 2009, 136, 26-31. [CrossRef] [PubMed]

37. Pardeike, J.; Hommoss, A.; Müller, R.H. Lipid nanoparticles (SLN, NLC) in cosmetic and pharmaceutical dermal products. Int. J. Pharm. 2009, 366, 170-184. [CrossRef] [PubMed]

38. Sun, W.; Mao, S.; Shi, Y.; Li, L.C.; Fang, L. Nanonization of itraconazole by high-pressure homogenization: Stabilizer optimization and effect of particle size on oral absorption. J. Pharm. Sci. 2011, 100, 3365-3373. [CrossRef] [PubMed]

39. Suárez-Jacobo, Á.; Gervilla, R.; Guamis, B.; Roig-Sagués, A.X.; Saldo, J. Effect of UHPH on indigenous microbiota of apple juice: A preliminary study of microbial shelf-life. Int. J. Food Microbiol. 2010, 136, 261-267. [CrossRef] [PubMed]

40. Velázquez-Estrada, R.M.; Hernández-Herrero, M.M.; López-Pedemonte, T.J.; Briñez-Zambrano, W.J.; Rüfer, C.E.; Guamis-López, B.; Roig-Sagués, A.X. Inactivation of Listeria monocytogenes and Salmonella enterica serovar Senftenberg $775 \mathrm{~W}$ inoculated into fruit juice by means of ultra-high-pressure homogenisation. Food Control. 2011, 22, 313-317. [CrossRef]

41. Velázquez-Estrada, R.M.; Hernández-Herrero, M.M.; Guamis-López, B.; Roig-Sagués, A.X. Impact of ultra-high-pressure homgenization on pectin methylesterase activity and microbial characteristics of orange juice: A comparative study against conventional heat pasteurization. Innov. Food Sci. Emerg. 2012, 13, 100-106. [CrossRef]

42. Donsì, F.; Ferrari, G.; Lenza, E.; Maresca, P. Main factors regulating microbial inactivation by high-pressure homogenization: Operating parameters and scale of operation. Chem. Eng. Sci. 2009, 64, 520-532. [CrossRef]

43. Maresca, P.; Donsì, F.; Ferrari, G. Application of a multi-pass high-pressure homogenization treatment for the pasteurization of fruit juices. J. Food Eng. 2011, 104, 364-372. [CrossRef]

44. Amador-Espejo, G.G.; Suàrez-Berencia, A.; Juan, B.; Bárcenas, M.E.; Trujillo, A.J. Effect of moderate inlet temperatures in ultra-high-pressure homogenization treatments on physicochemical and sensory characteristics of milk. J. Dairy Sci. 2014, 97, 659-671. [CrossRef] [PubMed]

45. Tahiri, I.; Makhlouf, J.; Paquin, P.; Fliss, I. Inactivation off food spoilage bacteria and Escherichia coli O157:H7 in phosphate buffer and orange juice using dynamic high pressure. Food Res. Int. 2006, 39, 98-105. [CrossRef]

46. Wuytack, E.Y.; Diels, A.M.J.; Michiels, C.W. Bacterial inactivation by high-pressure homogenisation and high hydrostatic pressure. Int. J. Food Microbiol. 2002, 77, 205-212. [CrossRef]

47. Grácia-Juliá, A.; René, M.; Cortés-Munoz, M.; Picart, L.; López-Pedemonte, T.; Chevalier, D.; Dumay, E. Effect of dynamic high pressure on whey protein aggregation: A comparison with the effect of continuous short-time thermal treatments. Food Hydrocoll. 2008, 22, 1014-1032. [CrossRef]

48. Eisenmenger, M.J.; Reyes de Corcuera, J.I. High-pressure enhancement of enzymes. Enzyme Microb. Technol. 2009, 45, 331-347. [CrossRef]

49. Gong, Z.; Li, D.; Liu, C.; Cheng, A.; Wang, W. Partial purification and characterization of polyphenol oxidase and peroxidase from chestnut kernel. LWT Food Sci. Technol. 2010, 60, 1095-1099. [CrossRef]

50. Martinez, M.V.; Whitaker, J.R. The biochemistry and control of enzymatic browning. Trends Food Sci. Technol. 1995, 6, 195-200. [CrossRef]

51. Elstner, E.F.; Heupel, A. Formation of hydrogen peroxide by isolated cell walls from horseradish (Amoracia lapathifolia Gilib.). Planta 1976, 130, 175-180. [CrossRef] [PubMed]

52. Sharma, R.J.; Gupta, R.C.; Saranjit, S.; Bansal, A.K.; Singh, I.P. Stability of anthocyanins- and anthocyanins-enriched extracts, and formulations of fruit pulp of Eugenia jambolana ("jamun"). Food Chem. 2016, 190, 808-817. [CrossRef] [PubMed] 
53. De Rosso, V.V.; Mercadante, A.Z. The high ascorbic acid content is the main cause of the low stability of anthocyanin extracts from acerola. Food Chem. 2007, 103, 935-943. [CrossRef]

54. Bąkowska-Barczak, A. Acylated anthocyanins as stable, natural food colorants. Pol. J. Food Nutr. Sci. 2005, 14, 107-116.

55. Torskangerpoll, K.; Andersen, O. Colour stability of anthocyanins in aqueous solution at various $\mathrm{pH}$ values. Food Chem. 2005, 89, 427-440. [CrossRef]

56. Chung, C.; Rojanasasithara, T.; Mutilangi, W.; McClements, D.J. Stability improvement of natural food colors: Impact of amino acid and peptide on anthocyanins stability in model beverages. Food Chem. 2017, 218, 277-284. [CrossRef] [PubMed]

57. Mercadante, A.Z.; Bobbio, F.O. Anthocyanins in Foods: Occurrence and Physicochemical Properties. In Food Colorants: Chemical and Functional Properties; Sociaciu, C., Ed.; CRC Press: Boca Raton, FL, USA, 2007.

58. Francis, F.J. Food colorants: Anthocyanins. Crit. Rev. Food Sci. 1989, 28, 273-314. [CrossRef] [PubMed]

59. Zhao, C.; Yu, Y.; Chen, Z.; Wen, G.; Wei, F.; Zheng, Q.; Wang, C.; Xiao, X. Stability-increasing effects of anthocyanins glycosyl acylation. Food Chem. 2017, 214, 119-128. [CrossRef] [PubMed]

60. Morild, E. The theory of pressure effects on enzymes. Adv. Protein Chem. 1981, 34, 93-166. [PubMed]

61. Cano, M.P.; Hernandez, A.; Ancos, B. High-pressure and thermal effects on enzyme inactivation in strawberry and orange products. J. Food Sci. 1997, 62, 85-88. [CrossRef]

62. Terefe, N.S.; Matthies, K.; Simons, L.; Versteeg, C. Combined high-pressure-mild temperature processing for optimal retention of physical and nutrition quality of strawberries (Fragaria $\times$ ananassa). Innov. Food Sci. Emerg. 2009, 10, 297-307. [CrossRef]

63. Terefe, N.S.; Yang, Y.H.; Knoerzer, K.; Buckow, R.; Versteeg, C. High-pressure and thermal inactivation kinetics of polyphenol oxidase and peroxidase in strawberry puree. Innov. Food Sci. Emerg. 2010, 11, 52-60. [CrossRef]

64. Terefe, N.S.; Kleintschek, T.; Gamage, T.; Fanning, K.J.; Netzel, G.; Versteeg, C.; Netzel, M. Comparative effect of thermal and high-pressure processing on phenolic phytochemicals in different strawberry cultivars. Innov. Food Sci. Emerg. 2013, 19, 57-65. [CrossRef]

65. Cao, X.; Zhang, Y.; Zhang, F.; Wang, Y.; Yi, J.; Liao, X. Effects of high hydrostatic pressure on enzymes, phenolic compounds, anthocyanins, polymeric color and color of strawberry pulps. J. Sci. Food Agric. 2011, 91, 877-885. [CrossRef] [PubMed]

66. Duong, T.; Balaban, M. Optimisation of the process parameters of combined high hydrostatic pressure and dense phase carbon dioxide on enzyme inactivation in feijoa (Acca sellowiana) puree using response surface methodology. Innov. Food Sci. Emerg. 2014, 26, 93-101. [CrossRef]

67. Chakraborty, S.; Rao, P.S.; Mishra, H.N. Kinetic modeling of polyphenoloxidase and peroxidase inactivation in pineapple (Ananas comosus L.) puree during high-pressure and thermal treatments. Innov. Food Sci. Emerg. 2015, 27, 57-68. [CrossRef]

68. Anese, M.; Nicoli, M.C.; Dall Aglio, G.; Lerici, C.R. Effect of high-pressure treatments on peroxidase and polyphenoloxidase activities. J. Food Biochem. 1995, 18, 285-293. [CrossRef]

69. Asaka, M.; Hayashi, R. Activation of Polyphenoloxidase in pear fruits by high-pressure treatment. Agric. Biol. Chem. 1991, 55, 2439-2440.

70. Butz, P.; Koller, W.D.; Tauscher, B.; Wolf, S. Ultra-high-pressure processing of onions: Chemical and sensory changes. LWT Food Sci. Technol. 1994, 27, 463-467. [CrossRef]

71. Jolibert, F.; Tonello, C.; Sagegh, P.; Raymond, J. Effect of high pressure on fruit polyphenol oxidase. BIOS 1994, 251, 27-35.

72. Weemaes, C.A.; Ludikhuyze, L.R.; van den Broeck, I.; Hendrickx, M.E. Kinetic of combined pressure-temperature inactivation of avocado polyphenoloxidase. Biotechnol. Bioeng. 1998, 60, 292-300. [CrossRef]

73. Sulaiman, A.; Silva, F.V.M. High pressure processing, thermal processing and freezing of "Camarosa" strawberry for the inactivation of polyphenoloxidase and control of browning. Food Control 2013, 33, 424-428. [CrossRef]

74. Garcia-Palazon, A.; Suthanthangjai, W.; Kajda, P.; Zabetakis, I. The effects of high pressure on $\beta$-glucosidase, peroxidase and polyphenoloxidase in red raspberry (Rubus idaeus) and strawberry (Fragaria $\times$ ananassa). Food Chem. 2004, 88, 7-10. [CrossRef] 
75. Chakraborty, S.; Baier, D.; Knorr, D.; Mishra, H.N. High pressure inactivation of polygalacturonase, pectinmethylesterase and polyphenoloxidase in strawberry puree mixed with sugar. Food Bioprod. Process. 2015, 95, 281-291. [CrossRef]

76. Marszałek, K.; Woźniak, Ł.; Skapska, S. Application of high pressure mild temperature processing for prolonging shelf-life of strawberry purée. High Press. Res. 2016, 36, 220-234. [CrossRef]

77. Finten, G.; Aguero, M.V.; Jagus, R.J.; Niranjan, K. High hydrostatic pressure blanching of baby spinach (Spinacia oleracea L.). LWT Food Sci. Technol. 2016, 73, 74-79. [CrossRef]

78. Kaushik, N.; Rao, P.S.; Mishra, H.N. Process optimalization for thermal-assisted high-pressure processing of mango (Mangifera indica L.) pulp using response surface methodology. LWT Food Sci. Technol. 2016, 69, 372-381. [CrossRef]

79. Terefe, N.S.; Delon, A.; Buckow, R.; Versteeg, C. Blueberry polyphenol oxidase: Characterization and the kinetics of thermal and high-pressure activation and inactivation. Food Chem. 2015, 188, 193-200. [CrossRef] [PubMed]

80. Garcia-Parra, J.; Gonzalez-Cebrino, F.; Delgado, J.; Cava, R.; Ramirez, R. High-pressure assisted thermal processing of pump kin puree: Effect on microbial counts, color, bioactive compounds and polyphenoloxidase enzyme. Food Bioprod. Process. 2016, 98, 124-132. [CrossRef]

81. Yi, J.; Kebede, B.T.; Dang, D.N.H.; Buve, C.; Grauwet, T.; Loey, A.V.; Hendrickx, M. Quality change during high-pressure processing and thermal processing of cloudy apple juice. LWT Food Sci. Technol. 2017, 75, 85-92. [CrossRef]

82. Liu, S.; Xu, Q.; Li, X.; Wang, Y.; Zhu, J.; Ning, C.; Chang, X.; Meng, X. Effects of high hydrostatic pressure on physicochemical properties, enzymes activity, and antioxidant capacities of anthocyanins extracts of wild Lonicera caerulea berry. Innov. Food Sci. Emerg. 2016, 36, 48-58. [CrossRef]

83. Paciulli, M.; Medina-Meza, I.G.; Chiavaro, E.; Barbosa-Canovas, G.V. Impact of thermal and high pressure processing on quality parameters of beetroot (Beta vulgaris L.). LWT Food Sci. Technol. 2016, 68, 98-104. [CrossRef]

84. Terefe, N.S.; Tepper, P.; Ullman, A.; Knoerzer, K.; Juliano, P. High-pressure thermal processing of pears: Effect on endogenous enzyme activity and related quality attributes. Innov. Food Sci. Emerg. 2016, 33, 56-66. [CrossRef]

85. Marszałek, K.; Skapska, S.; Woźniak, Ł.; Sokołowska, B. Application of supercritical carbon dioxide for the preservation of strawberry juice: Microbial and physicochemical quality, enzymatic activity and the degradation kinetics of anthocyanins during the storage. Innov. Food Sci. Emerg. 2015, 32, 101-109. [CrossRef]

86. Marszałek, K.; Skapska, S.; Woźniak, Ł. Effect of supercritical carbon dioxide on selected quality parameters of preserved strawberry juice. Food Sci. Technol. Quality 2015, 2, 114-123. [CrossRef]

87. Gui, F.; Wu, J.; Chen, F.; Liao, X.; Hu, X.; Zhang, Z.; Wang, Z. Inactivation of polyphenol oxidases in cloudy apple juice exposed to supercritical carbon dioxide. Food Chem. 2007, 100, 1678-1685. [CrossRef]

88. Del Pozo-Insfran, D.; Balaban, M.O.; Talcott, S.T. Inactivation of polyphenol oxidase in muscadine grape juice by dense phase-CO $\mathrm{CO}_{2}$ processing. Food Res. Int. 2007, 40, 894-899. [CrossRef]

89. Zhou, L.; Wang, Y.; Hu, X.; Wu, J.; Liao, X. Effect of high pressure carbon dioxide on the quality of carrot juice. Innov. Food Sci. Emerg. 2009, 10, 321-327. [CrossRef]

90. Spilimbergo, S.; Komes, D.; Vojvodic, A.; Levaj, B.; Ferretino, G. High-pressure carbon dioxide pasteurization of fresh-cut carrot. J. Supercrit. Fluids 2013, 79, 92-100. [CrossRef]

91. Niu, S.; Xu, Z.; Fang, Y.; Zhang, L.; Yang, Y.; Liao, X.; Hu, X. Comparative study on cloudy apple juice qualities from apple slices treated by high-pressure carbon dioxide and mild heat. Innov. Food Sci. Emerg. 2010, 11, 91-97. [CrossRef]

92. Brownmiller, C.; Howard, L.R.; Prior, R.L. Processing and storage effects on monomeric anthocyanins, percent polymeric color, and antioxidant capacity of processed blueberry products. J. Food Sci. 2008, 73, 72-79. [CrossRef] [PubMed]

93. Srivastava, A.; Ahkoh, C.C.; Yi, W.; Fischer, J.; Krewer, G. Effect of storage conditions on the biological activity of phenolic compounds of blueberry extract packed in glass bottles. J. Agric. Food Chem. 2007, 55, 2705-2713. [CrossRef] [PubMed]

94. Hirsch, A.R.; Alexandra, K.; Carle, R.; Neidhart, S. Impact of minimal heat-processing on pectin methylesterase and peroxidase activity in freshly squeezed citrus juices. Eur. Food Res. Technol. 2011, 232, 71-81. [CrossRef] 
95. Navarro, J.L.; Izquierdo, L.; Carbonell, J.V.; Sentandreu, E. Effect of pH, temperature and maturity on pectinmethylesterase inactivation of citrus juices treated by high-pressure homogenization. LWT Food Sci. Technol. 2014, 57, 785-788. [CrossRef]

96. Floury, J.; Bellettre, J.; Legrand, J.; Desrumaux, A. Analysis of new type of high-pressure homogeniser. A study of the flow pattern. Chem. Eng. Sci. 2004, 59, 843-853. [CrossRef]

97. Cruz, N.S.; Capellas, M.; Hernández, M.; Trujillo, A.J.; Guamis, B.; Ferragut, V. Ultra-high-pressure homogenization of soymilk: Microbiological, physicochemical and microstructural characteristics. Food Res. Int. 2007, 40, 725-732. [CrossRef]

98. Lacroix, N.; Fliss, I.; Makhlouf, J. Inactivation of pectin methylesterase and stabilization of opalescence in orange juice by dynamic high-pressure. Food Res. Int. 2005, 38, 569-576. [CrossRef]

99. Balny, C.; Masson, P. Effects of high-pressure on proteins. Food Rev. Int. 1993, 9, 611-628. [CrossRef]

100. Welti-Chanes, J.; Ochoa-Velasco, C.E.; Guerrero-Beltrán, J.Á. High-pressure homogenization of orange juice to inactivate pectinmethylesterase. Innov. Food Sci. Emerg. 2009, 10, 457-462. [CrossRef]

101. Karacam, C.H.; Sahin, S.; Oztop, M.H. Effect of high pressure homogenization (microfluidization) on the quality of Ottoman strawberry (F. Ananassa) juice. LWT Food Sci. Technol. 2015, 64, 932-937. [CrossRef]

102. Carreño, J.M.; Gurrea, M.C.; Sampedro, F.; Carbonell, J.V. Effect of high hydrostatic pressure and high-pressure homogenisation on Lactobacillus plantarum inactivation kinetics and quality parameters of mandarin juice. Eur. Food Res. Technol. 2011, 232, 265-274. [CrossRef]

103. McKay, M.A.; Linton, M.; Stirling, J.; Mackle, A.; Patterson, F.M. A comparative study of changes in the microbiota of apple juice treated by high hydrostatic pressure (HHP) or high pressure homogenisation (HPH). Food Microbiol. 2011, 28, 1426-1431. [CrossRef] [PubMed]

104. Ferrari, G.; Maresca, P.; Ciccarone, R. The effects of high hydrostatic pressure on the polyphenols and anthocyanins in red fruit products. Procedia Food Sci. 2011, 1, 847-853. [CrossRef]

105. Verbeyst, L.; Hendrickx, M.; Loey, A. Charakterisation and screening of the process stability of bioactive compounds in red fruit paste and red fruit juice. Eur. Food Res. Technol. 2012, 234, 593-605. [CrossRef]

106. Corrales, M.; Butz, P.; Tausher, B. Anthocyanin condensation reactions under high hydrostatic pressure. Food Chem. 2008, 110, 627-635. [CrossRef]

107. Barba, F.J.; Esteve, M.J.; Frigola, A. Physicochemical and nutritional characteristic of blueberry juice after high pressure processing. Food Res. Int. 2013, 50, 545-549. [CrossRef]

108. Ferrari, G.; Maresca, P.; Ciccarone, R. The application of high hydrostatic pressure for the stabilization of functional foods: Pomegranate juice. J. Food Eng. 2010, 100, 245-253. [CrossRef]

109. Bodelón, O.G.; Avizcuri, J.M.; Fernández-Zurbano, P.; Dizy, M.; Préstamo, G. Pressurization and cold storage of strawberry purée: Colour, anthocyanins, ascorbic acid and pectin methylesterase. LWT Food Sci. Technol. 2013, 52, 123-130. [CrossRef]

110. Fabroni, S.; Amenta, M.; Timpanaro, N.; Rapisarda, P. Supercritical carbon dioxide-treated blood orange juice as a new product in the fresh juice market. Innov. Food Sci. Emerg. 2010, 11, 477-484. [CrossRef]

111. Ramirez-Rodrigues, M.M.; Plaza, M.L.; Azeredo, A.; Balaban, M.O.; Marshall, M.R. Phytochemical, sensory attributes and aroma stability of dense phase carbon dioxide processed Hibiscus sabdariffa beverage during storage. Food Chem. 2012, 134, 1425-1431. [CrossRef] [PubMed]

112. Zou, H.; Lit, T.; Bi, X.; Zhao, L.; Wang, Y.; Liao, X. Comparison of high hydrostatic pressure, high-pressure carbon dioxide and high-temperature short-time processing on quality of mulberry juice. Food Bioprocess. Technol. 2016, 9, 217-231. [CrossRef]

113. Del Pozo-Insfran, D.; Balaban, M.O.; Talcott, S.T. Microbial stability, phytochemical retention, and organoleptic attributes of dense phase $\mathrm{CO}_{2}$ processed muscadine grape juice. J. Agric. Food Chem. 2006, 54, 5468-5473. [CrossRef] [PubMed]

114. Del Pozo-Insfran, D.; Balaban, M.O.; Talcott, S.T. Enhancing the retention of phytochemicals and organoleptic attributes in muscadine grape juice through a combined approach between dense phase $\mathrm{CO}_{2}$ processing and copigmentation. J. Agric. Food Chem. 2006, 54, 6705-6712. [CrossRef] [PubMed]

115. Danişman, G.; Arslan, E.; Toklucu, A.K. Kinetic analysis of anthocyanin degradation and polymeric colour formation in grape juice during heating. Czech J. Food Sci. 2015, 33, 103-108. [CrossRef]

116. Syamaladevi, R.M.; Insan, S.K.; Dhawan, S.; Andrews, P.; Sablani, S.S. Physicochemical properties of encapsulated red raspberry (Rubus idaeus) powder: Influence of high-pressure homogenization. Dry Technol. 2012, 30, 484-493. [CrossRef] 
117. Guan, Y.; Zhong, Q. The improved thermal stability of anthocyanins at pH 5.0 by gum Arabic. LWT Food Sci. Technol. 2015, 64, 706-712. [CrossRef]

118. Kouniaki, S.; Kajda, P.; Zabetakis, I. The effect of high hydrostatic pressure on anthocyanins and ascorbic acid in blackcurrant (Ribes nigrum). Flavour Fragr. J. 2004, 19, 281-286. [CrossRef]

119. Zabetakis, I.; Koulentianos, A.; Orruno, E.; Boyes, I. The effect of high hydrostatic pressure on strawberry flavour compounds. Food Chem. 2000, 71, 51-55. [CrossRef]

120. Suthanthangjai, W.; Kajda, P.; Zabetakis, I. The effect of high hydrostatic pressure on the anthocyanins of raspberry (Rubus ideus). Food Chem. 2005, 90, 193-197. [CrossRef]

121. Gimenez, J.; Kajda, P.; Margomenou, L.; Piggott, J.R.; Zabetakis, I. A study on the color and sensory attributes of high hydrostatic pressure jams as compared with traditional jams. J. Sci. Food Agric. 2001, 81, 1228-1234. [CrossRef]

122. Del Pozo-Insfran, D.; del Follo-Martinez, A.; Talcott, S.T.; Brenes, C.H. Stability of copigmented anthocyanins and ascorbic acid in muscadine grape juice processes by high hydrostatic pressure. J. Food Sci. 2007, 72, 247-253. [CrossRef] [PubMed]

123. Cao, X.; Bi, X.; Huang, W.; Wu, J.; Hu, X.; Liao, X. Changes of quality of high hydrostatic pressure processed cloudy and clear strawberry juices during storage. Innov. Food Sci. Emerg. 2012, 16, 181-190. [CrossRef]

124. Marszałek, K.; Woźniak, Ł.; Skąpska, S.; Mitek, M. High-pressure processing, and thermal pasteurization of strawberry puree: Quality parameters, and shelf life evaluation during cold storage. J. Food Sci. Technol. Mysore 2017. [CrossRef]

125. Gao, G.; Ren, P.; Cao, X.; Yan, B.; Liao, X.; Sun, Z.; Wang, Y. Comparing quality changes of cupped strawberry treated by high hydrostatic pressure ant thermal processing during storage. Food Bioprod. Process. 2016, 100, 221-229. [CrossRef]

126. Yu, Y.; Lin, Y.; Zhan, Y.; He, J.; Zhu, S. Effect of high pressure processing on the stability of anthocyanins, ascorbic acid and color of Chinese bayberry juice during storage. J. Food Process. 2013, 119, 701-706. [CrossRef]

127. Chen, D.; Xi, H.; Guo, X.; Qin, Z.; Pang, X.; Hu, X.; Liao, X.; Wu, J. Comparative study of quality of cloudy pomegranate juice treated by high hydrostatic pressure and high temperature short time. Innov. Food Sci. Emerg. 2013, 19, 85-94. [CrossRef]

128. Błaszczak, W.; Amarowicz, R.; Górecki, A. Antioxidant capacity, phenolic composition and microbial stability of aronia juice subjected to high hydrostatic pressure processing. Innov. Food Sci. Emerg. 2017, 39, 141-147. [CrossRef]

(C) 2017 by the authors; licensee MDPI, Basel, Switzerland. This article is an open access article distributed under the terms and conditions of the Creative Commons Attribution (CC BY) license (http://creativecommons.org/licenses/by/4.0/). 